\title{
Tributary-Stream Infiltration in Marsh Creek Valley, North-Central Pennsylvania
}

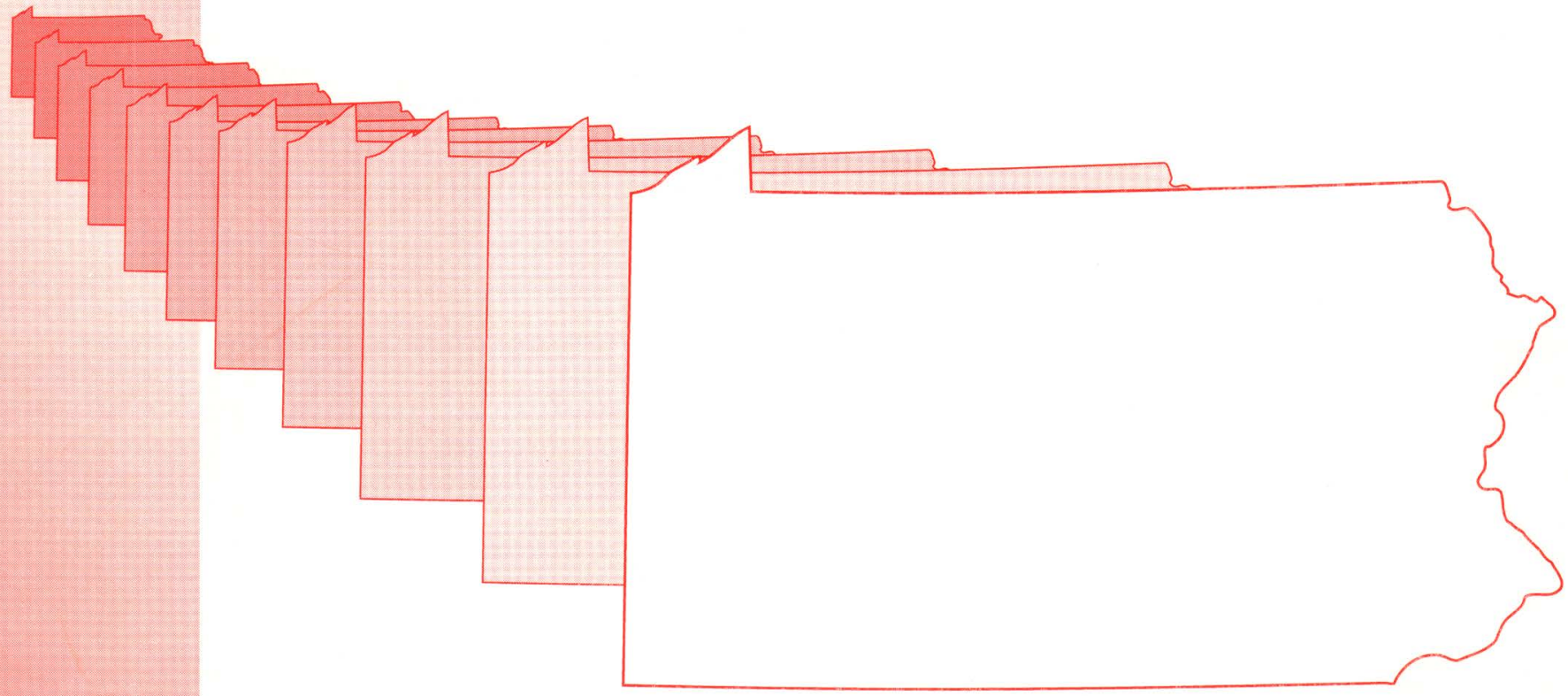

U.S. GEOLOGICAL SURVEY

Water-Resources Investigations Report 90-4052

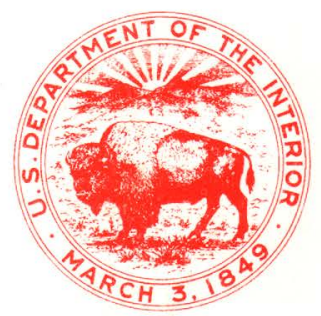





\section{TRIBUTARY-STREAM INFILTRATION IN MARSH CREEK VALLEY, NORTH-CENTRAL PENNSYLVANIA}

by John $\mathrm{H}$. Williams

U.S. GEOLOGICAL SURVEY

Water-Resources Investigation Report 90-4052

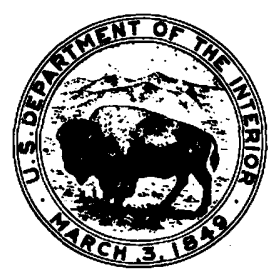

Albany, New York 
DEPARTMENT OF THE INTERIOR

MANUEL LUJAN, Jr., Secretary

\section{U.S. GEOLOGICAL SURVEY}

Dallas L. Peck, Director

For additional information write to:

U.S. Geological Survey

343 Post Office \& Courthouse

Post Office Box 1669

Albany, NY 12201
Copies of this report may purchased from:

Books and Open-File Reports

U.S. Geological Survey

Federal Center, Bldg. 41

Box 25425

Denver, CO 80225 


\section{CONTENTS}

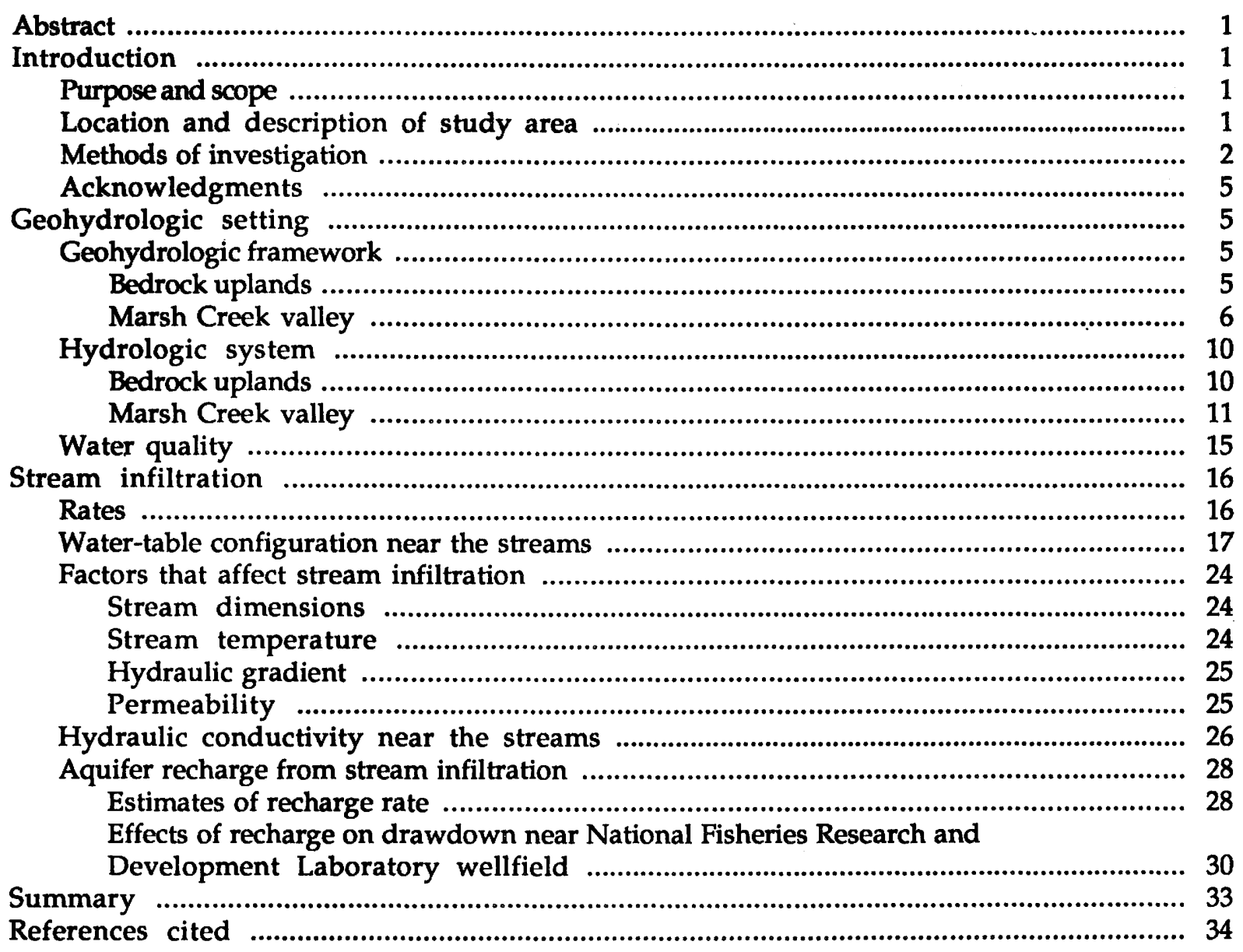

\section{ILLUSTRATIONS}

Figure 1-5. Maps showing :

1. Principal geographic features and location of study area ..................................... 2

2. Location of Marsh Creek, tributary streams studied, and the National Fisheries Research and Development Laboratory

3. Upland drainage-basin boundaries of the tributary streams

4. Surficial geology of Marsh Creek valley

5. Bedrock geology of Marsh Creek valley and upland drainage basins of the tributary streams 


\section{ILLUSTRATIONS (continued)}

Figure 6. Map showing location of data-collection sites

7. Hydrographs showing streamflow from the upland drainage basins of Asaph and Straight Runs and estimated precipitation, water year 1985

8. Graph showing pumping rate at the National Fisheries Research and Development Laboratory wellfield, water year 1985

9. Hydrograph showing water levels in well 470 near Straight Run and well 471 near Asaph Run, water year 1985

10. Map showing water levels in selected wells and at staff gages near Asaph and Straight Runs, October 10, 1984; March 30, 1985; and September 8, 1985

11. Hydrograph showing average water levels for October in well 1 near Long Run, 8 miles west of the study area, 1935-1985

12. Diagrams showing major cation and anion concentrations in water sampled at selected sites

13-21. Graphs showing:

13. Cumulative infiltration along the tributary streams 18

14. Ground-water levels in relation to distance from farthest downstream bedrock outcrop along Asaph and Straight Runs

15. Ground-water levels in relation to distance from Asaph and Straight Runs

16. Relation between water levels in well 348 and position of the point of stream dryness along Asaph Run, June through September 1985

17. Water levels in selected wells near Asaph Run, water year 1985

18. Infiltration rate for Asaph and Straight Runs in relation to (A) wetted perimeter, and (B) stream temperature

19. Infiltration rate along Asaph and Straight Runs in relation to hydraulic gradient

20. Relation between ratio of infiltration to hydraulic conductivity and ratio of depth of ground water to stream width....

21. Streamflow from the upland drainage basins and infiltration in Marsh Creek valley for Asaph and Straight Runs, water year 1985.

22. Map showing location of pumped well and selected observation wells and points of stream dryness in Straight Run for aquifer tests of November 7-10, 1977 and September 5-8 and 16-20, 1985, at the National Fisheries Research and Development Laboratory wellfield 


\section{ILLUSTRATIONS (continued)}

Figure 23. Graphs showing water levels in selected observation wells during aquifer tests at the National Fisheries Research and Development Laboratory wellfield on:

A. November 7-10, 1977 and September 5-8, 1985. B. September 16-20, 1985

\section{PLATE}

(in pocket)

Plate 1. Sections showing subsurface geology near the tributary streams.

\section{TABLES}

Table 1. Drainage-basin area and gradient of the tributary streams and Marsh Creek

2. Geohydrologic characteristics of the postglacial and glacial deposits and bedrock ..... 8

3. Summary of selected specific-capacity tests in the stratified-drift aquifer near Straight and Asaph Runs

4. Specific conductance and hardness of water sampled at selected stream and well sites

5. Infiltration rates along the tributary streams

6. Water levels and completion information in relation to stream surface for selected wells near the tributary streams

7. Stream-infiltration variables and estimated hydraulic conductivity near the tributary streams

8. Sources and estimated rates of recharge to the stratified-drift aquifer in Marsh Creek valley, water year 1985

9. Monthly and annual averages of streamflow from the upland drainage basins and infiltration in Marsh Creek valley for Asaph and Straight Runs, water year 1985

10. Summary of selected aquifer tests at the National Fisheries Research and Development Laboratory wellfield

\section{APPENDIXES}

Appendix 1. Completion information for the selected wells and test holes

2. Streamflow and infiltration rates for the tributary-stream sites 


\section{CONVERSION FROM INCH-POUND SYSTEM TO SI (METRIC) UNITS}

For the convenience of readers who prefer metric (International System) units rather than the inchpound units in this report, the following conversion factors may be used.:

Multiply inch-pound unit

inch (in)

foot (ft)

mile (mi)

degree Fahrenheit $\left({ }^{\circ} \mathrm{F}\right)$

square mile $\left(\mathrm{mi}^{2}\right)$

gallon (gal)

gallon per minute (gal/min)

cubic foot per second $\left(\mathrm{ft}^{3} / \mathrm{s}\right)$

inch per year (in/yr)

foot per day (ft/d)
By

To obtain metric unit

Length

25.4

0.3048

1.609

Temperature

$5 / 9\left({ }^{\circ} \mathrm{F}-32\right)$

Area

2.59

Volume

3.785

liter (L)

Flow

0.06308
0.02832
25.4

liter per second $(\mathrm{L} / \mathrm{s})$

cubic meter per second $\left(\mathrm{m}^{3} / \mathrm{s}\right)$

millimeter per year $(\mathrm{mm} / \mathrm{yr})$ millimeter (mm)

meter (m)

kilometer (km)

degree Celsius $\left({ }^{\circ} \mathrm{C}\right)$

square kilometer $\left(\mathrm{km}^{2}\right)$
Hydraulic Conductivity

0.3048

Sea level: In this report "sea level" refers to the National Geodetic Vertical Datum of 1929

(NGVD of 1929)--a geodetic datum derived from a general adjustment of the first-order level nets of both the United States and Canada, formerly called "Sea level datum of 1929." 


\title{
TRIBUTARY-STREAM INFILTRATION IN MARSH CREEK VALLEY, NORTH-CENTRAL PENNSYLVANIA
}

\author{
By John H. Williams
}

\begin{abstract}
The geohydrology of infiltration from five tributary streams along a 3.6-mile reach of Marsh Creek valley in north-central Pennsylvania was investigated during 1983-85. Marsh Creek valley is underlain by up to 100 feet of stratified drift that overlies Devonian bedrock. The stratified drift is overlain by up to 30 feet of alluvialfan deposits near the tributary streams.

Four of the five tributary streams lose large amounts of water to the stratified-drift aquifer in Marsh Creek valley. Along reaches away from the valley wall, infiltration losses from the streams averaged about 2 cubic feet per second $\left(\mathrm{ft}^{3} / \mathrm{s}\right)$ per 1,000 feet of wetted channel length. Estimated hydraulic conductivity of the deposits near these streams ranges from 31 to 100 feet per day and averages 61 feet per day. Silty beds of lower permeability near the streams may significantly affect infiltration. The low permeability of the sediments near the fifth stream, which probably consist
\end{abstract}

largely of fine-grained alluvium and swamp deposits, may account for the lack of infiltration losses along this stream.

Tributary-stream infiltration accounted for more than 70 percent of the estimated recharge to the stratified-drift aquifer along the reach investigated during water year 1985, in which annual precipitation was below average. The sources of recharge and their estimated rates were: (1) direct infiltration of precipitation on the valley, $1.7 \mathrm{ft}^{3} / \mathrm{s}$; (2) unchanneled runoff and ground-water inflow from the uplands, 2.7 $\mathrm{ft}^{3} / \mathrm{s}$; and (3) tributary-stream infiltration from Asaph Run, $3.7 \mathrm{ft}^{3} / \mathrm{s}$, Straight Run, $3.7 \mathrm{ft}^{3} / \mathrm{s}$, Dantz Run, $1.2 \mathrm{ft}^{3} / \mathrm{s}$ and Canada Run, $1.9 \mathrm{ft}^{3} / \mathrm{s}$. The temporal variation in recharge from tributary-stream infiltration greatly affects drawdowns caused by pumping from the wellfield at the National Fisheries Research and Development Laboratory near Straight Run.

\section{INTRODUCTION}

Infiltration from tributary streams that drain bedrock uplands is an important source of recharge for many valley aquifers in the United States. These aquifers include (1) alluvial-basin aquifers in the Southwest Basin and Range (Babcock and Cushing, 1942); (2) carbonate-rock aquifers in the Appalachian Valley and Ridge (Becher and Root, 1981); and (3) stratified-drift aquifers in the glaciated Appalachian Plateau (Randall, 1978). In 1983, the U.S. Geological Survey began a study of tributary-stream infiltration to stratified-drift aquifers as part of its Northeast Glacial Regional Aquifer-System Analysis Program (Lyford, 1986). Two sites were selected for detailed investigation of tributary stream and aquifer systems-the Saco River valley in eastern New Hampshire and Marsh Creek valley in north-central Pennsylvania.

\section{Purpose and Scope}

This report presents results of the geohydrologic investigation of infiltration from five tributary streams in Marsh Creek valley, $\mathrm{Pa}$., in 1983-85. The report includes (1) maps and sections showing the geohydrologic setting of the tributary streams; (2) graphs and tables of the infiltration rates along the streams; (3) maps and sections showing the water-table configuration near the streams; (4) discussion of the factors that affect tributary-stream infiltration; and (5) estimates of the magnitude and distribution of recharge from tributary-stream infiltration and the effect of this recharge on drawdown in the stratified-drift aquifer.

\section{Location and Description of Study Area}

The study area is in Marsh Creek valley and surrounding uplands 8 miles northwest of Wellsboro in Tioga County, north-central Pennsylvania (fig. 1). The study area is in the glaciated part of the Appalachian Plateau, which is characterized by till-mantled bedrock uplands and steep-sided valleys that contain thick deposits of stratified drift. The late 
Wisconsinan glacial border is $\mathbf{1 0}$ miles southeast of the study area. Marsh Creek is in the drainage basin of the West Branch of the Susquehanna River and drains into Pine Creek 5 miles downstream of the study area.

Five tributary streams along a 3.6-mile reach of Marsh Creek were selected for study. From west to east, they are Asaph, Straight, Dantz, Canada, and Heise Runs (fig. 2). The tributary streams have upland drainage basin areas ranging from 2.5 to 16.3 square miles (table 1 and fig. 3). Asaph Run has the largest basin area, and Heise Run has the smallest. Asaph Run in Marsh Creek valley has a gradient of 1.3 percent, and Straight, Dantz, Canada, and Heise Runs have gradients of 1.7 to 1.8 percent. Marsh Creek has a gradient of only 0.05 percent.
The National Fisheries Research and Development Laboratory of the U.S. Fish and Wildlife Service is near Straight Run in Marsh Creek valley (fig. 2). Preliminary geotechnical investigations of the site were made in 1973 before construction of the National Fisheries Research and Development Laboratory. Construction started at the site in May 1977, and the facility began operation in October 1978.

\section{Methods of Investigation}

The geohydrology of tributary-stream infiltration in the study area was investigated by surficial geologic mapping; surface geophysics; inventory of wells and test holes; test-hole drilling; measurement of streamflow, groundwater and surface-water levels, and pumping

Table 1.-Drainage-basin area and gradient of the tributary streams and Marsh Creek

[Locations are shown in fig. 2]

\begin{tabular}{lcc}
\hline Stream name & $\begin{array}{l}\text { Upland drainage-basin area, } \\
\text { in square miles }\end{array}$ & $\begin{array}{l}\text { Stream gradient in Marsh } \\
\text { Creek valley, in percent }\end{array}$ \\
\hline Asaph Run & & 1.3 \\
Straight Run & 16.3 & 1.8 \\
Dantz Run & 7.0 & 1.7 \\
Canada Run & 4.0 & 1.8 \\
Heise Run & 4.3 & 1.7 \\
Marsh Creek & 2.5 & .05 \\
\hline
\end{tabular}

a Includes valley area.

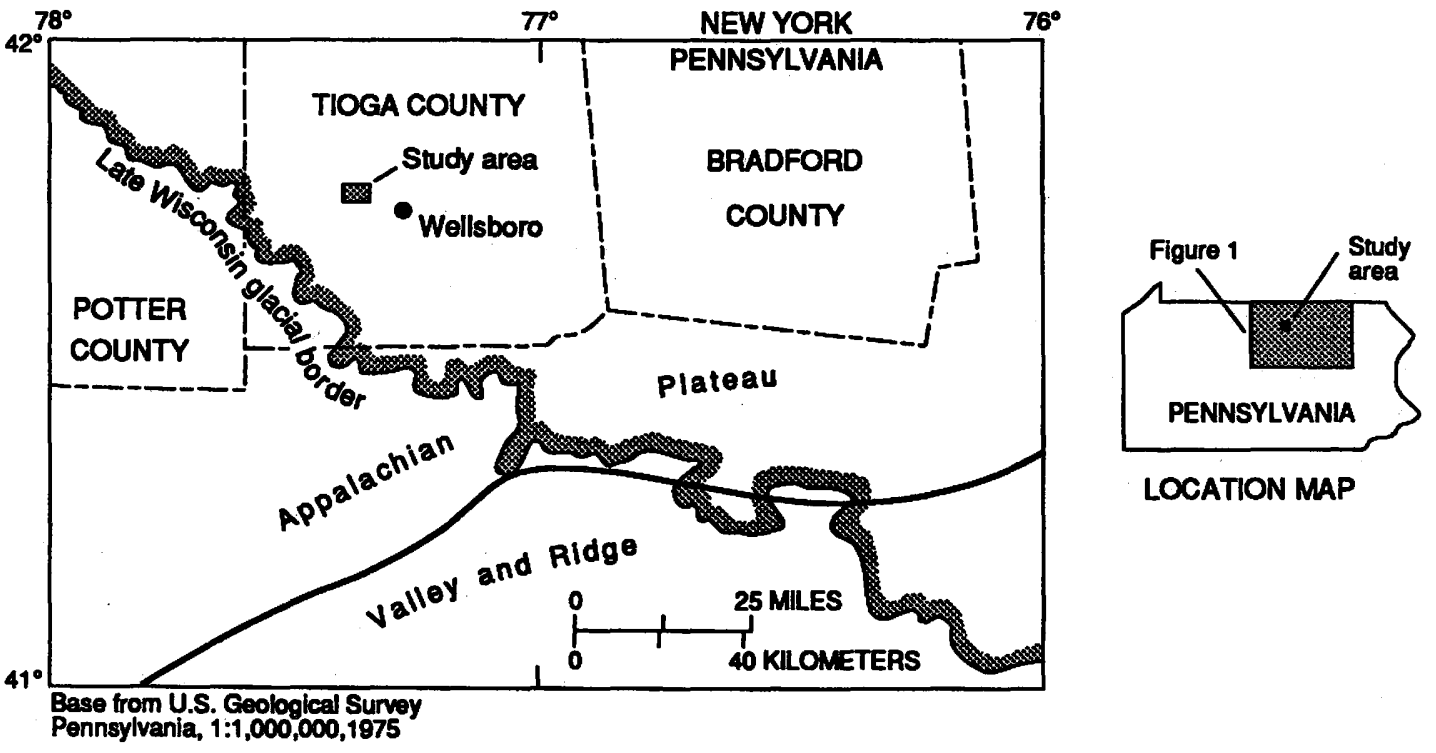

Figure 1.--Principal geographic features and location of study area 


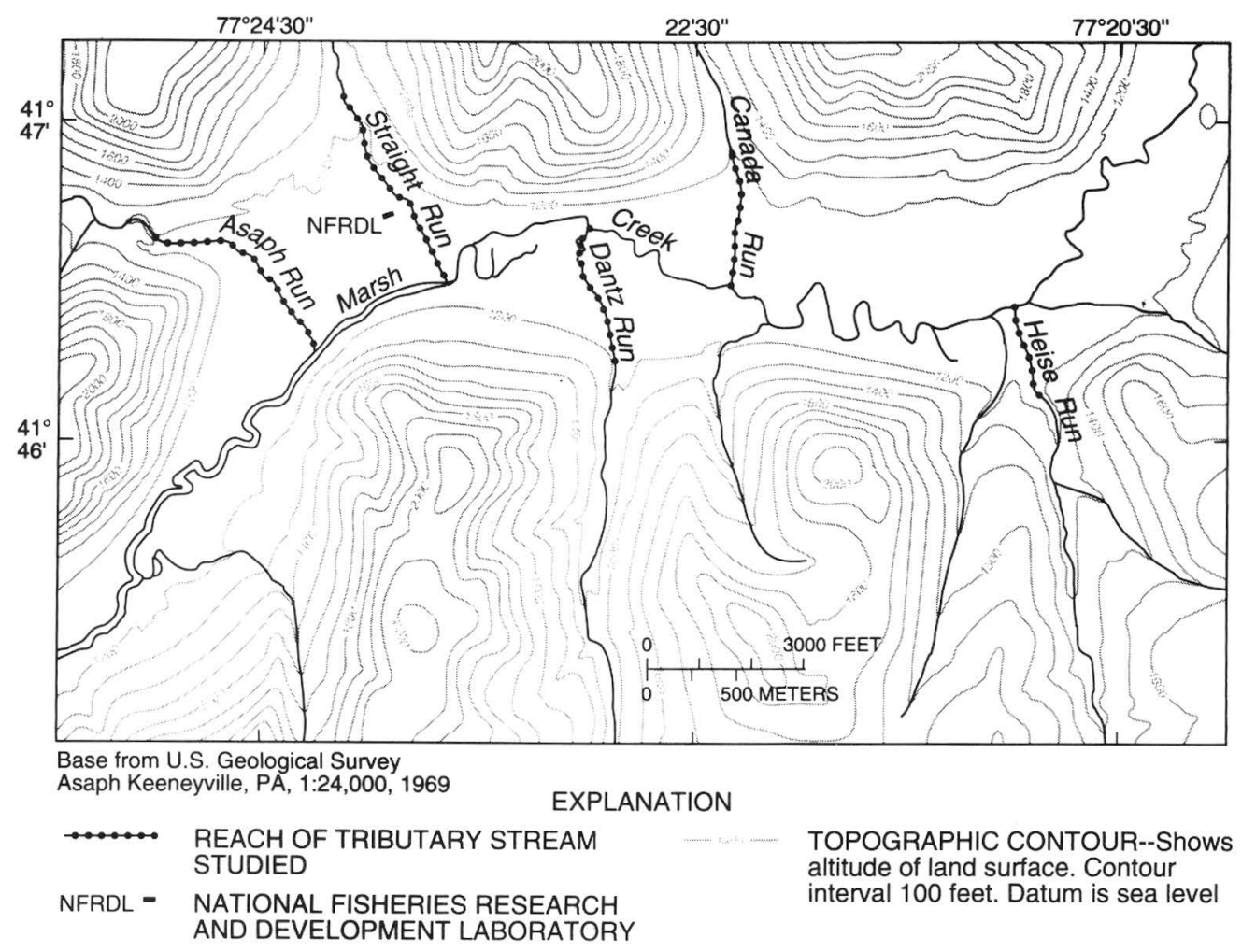

Figure 2.--Location of Marsh Creek, tributary streams studied, and the National Fisheries Research and Development Laboratory.

rates; and collection and analysis of waterquality samples. The surficial geologic mapping was completed by the Pennsylvania Geological Survey as part of a cooperative project on the stratified-drift aquifers of Bradford, Tioga, and Potter Counties. The resulting map was modified in accordance with additional geologic data collected during the present investigation.

Surface-geophysical methods used in the study include direct-current resistivity and seismic refraction. Resistivity soundings were completed to characterize the glacial and postglacial deposits at nine sites near the tributary streams. The resistivity method is explained in detail by Zhody and others (1974). The resistivity of unconsolidated deposits is affected by grain size, degree of saturation, and dissolved-solids concentration of ground water. In general, resistivity increases with increasing grain size and decreasing saturation and dissolved-solids concentration. The resistivity of saturated coarse-grained stratified-drift deposits in the study area exceeds $300 \mathrm{ohm}$-meters; that of saturated fine-grained deposits is less than 200 ohm-meters. The resistivity of the bedrock buried by stratified drift in the valley appears to be similar to that of the fine-grained deposits. The Schlumberger electrode array was used, and the resistivity data were interpreted with the aid of a computer program developed by Zhody (1973).

A seismic-refraction survey was done near Straight Run to determine the depth to the water table and bedrock. Haeni (1988) describes the application of the seismic-refraction method in the investigation of stratified-drift aquifers. The seismic-refraction survey was interpreted with the aid of a computer program developed by Scott and others (1972). The seismic velocities determined for unsaturated and saturated unconsolidated deposits and sedimentary bedrock from the survey near Straight Run are in close agreement with those presented by Haeni (1986) for similar units in New England.

Completion information, geologic logs, and aquifer-test data were collected from 59 wells and test holes by field inventory and compilation of unpublished reports by drillers and consultants. 


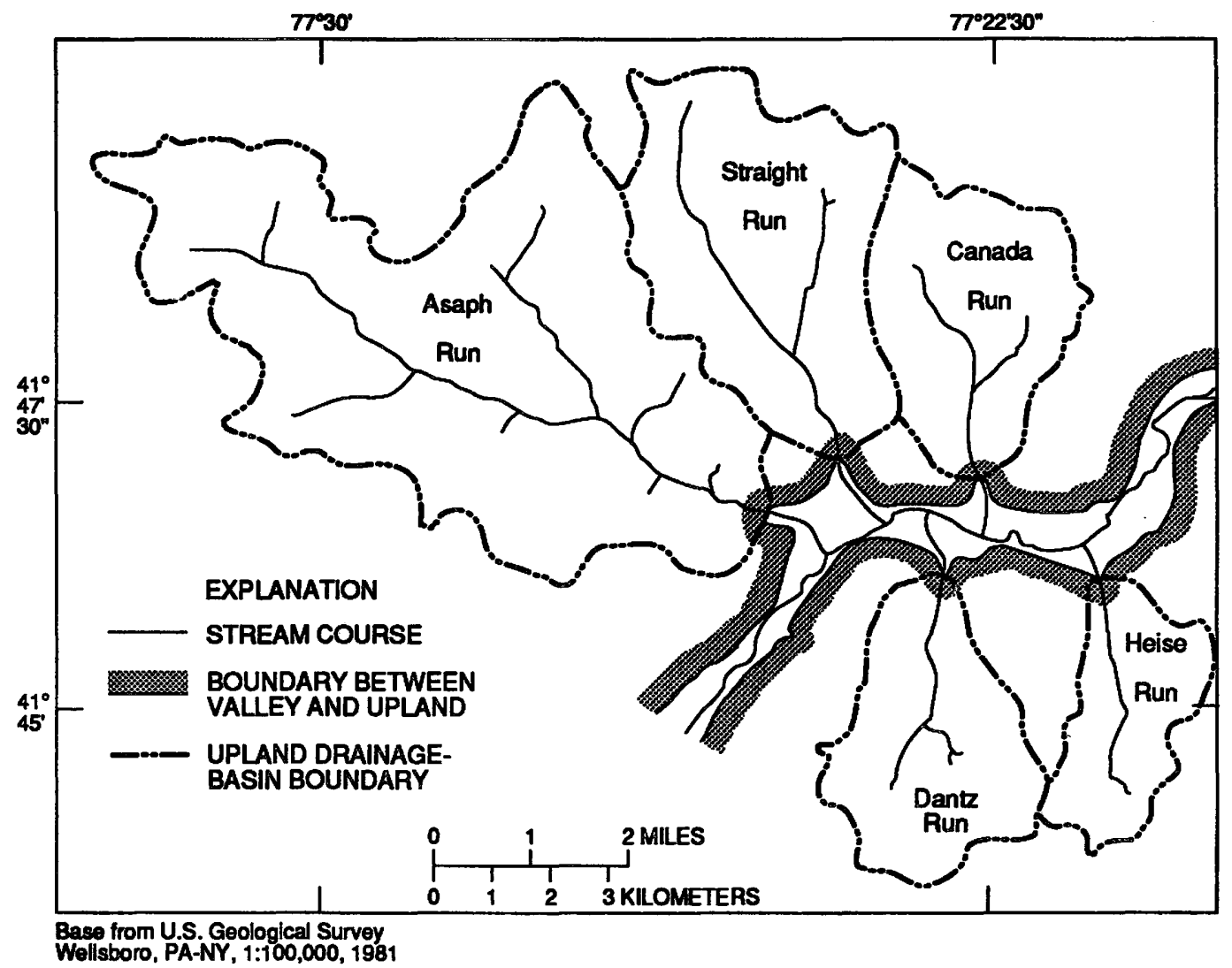

Figure 3.--Upland drainage-basin boundaries of the tributary streams.

Twelve test holes were drilled for this study; 10 of these were drilled by the hollow-stem auger method, and geologic samples were collected with a split-spoon sampler. The auger holes were completed as observation wells with 2-inchdiameter plastic casing and 5 feet of screen at the bottom. The other two holes were drilled by the cable-tool method, and geologic samples were collected with a bailer or sand pump. The cabletool holes were completed as observation wells with 6-inch-diameter steel casing and 5 feet of slotted casing at the bottom. Specific-capacity tests were completed at the 6-inch-diameter wells. Geologic samples also were collected from 11 domestic wells that were drilled by the U.S. Fish and Wildlife Service to replace shallower wells near the National Fisheries Research and Development Laboratory (fig. 3). The geologic samples from the test holes and wells were analyzed for grain size, sand and pebble lithology, and the presence of organic materials.

A streamflow-measurement site was established along each of the tributary streams near the farthest downstream point where the stream channel is on bedrock. Two or more measurement sites were established farther downstream in Marsh Creek valley. Sets of streamflow measurements were made during baseflow conditions or during declining flow after storms to determine stream-infiltration rates. When a tributary went dry, the point of dryness was located. One set of streamflow measurements was made along each tributary stream in July 1983, and from 5 to 14 sets of streamflow measurements were made between May 1984 and October 1985. During water year 1985 (October 1, 1984 to September 30, 1985), sets of streamflow measurements were made about monthly along Asaph and Straight Runs.

Staff gages were constructed at the nine streamflow-measurement sites along Asaph and Straight Runs. Stilling wells with stage recorders were installed at upstream sites near the valley wall on these two streams, and continuous records of streamflow were collected from July 1984 through September 1985 by 
methods described by Kennedy (1984). Surfacewater levels were measured at the staff gages periodically between July 1984 and October 1985. During water year 1985, surface-water levels and points of stream dryness on these two streams were measured weekly and more frequently after selected storms.

A network of 24 observation wells was established in selected areas along the tributary streams. Ground-water levels were measured periodically between May 1984 and October 1985. During water year 1985, water levels were measured weekly and more frequently after selected storms in the observation wells along Asaph, Straight, and Heise Runs.

Two aquifer tests were completed by the U.S. Geological Survey and U.S. Fish and Wildlife Service in September 1985 at the National Fisheries Research and Development Laboratory wellfield. Data on pumping rates, ground-water levels in more than 20 observation wells, and stream infiltration along Straight and Asaph Runs were collected periodically during the tests. During the first test, all water pumped from the wellfield was discharged to Marsh Creek, but during the second test, some was discharged to
Straight Run upstream of the wellfield.

Samples of ground water and surface water were collected at 12 sites and were analyzed in the field for specific conductance and hardness. Water-quality samples from 8 sites were analyzed for total dissolved solids, major cation and anions, and metals by the Pennsylvania Department of Environmental Resources as part of the cooperative project with the Pennsylvania Geological Survey.

\section{Acknowledgments}

The author expresses appreciation to the residents of the study area for allowing access to private property and wells. The cooperation of the staff of the National Fisheries Research and Development Laboratory also is greatly appreciated. Special thanks are extended to Michael Smith of the National Fisheries Research and Development Laboratory for his extra time and effort. Lawrence Taylor of the Susquehanna River Basin Commission is acknowledged for his technical support to the study while working for the Pennsylvania Geological Survey.

\section{GEOHYDROLOGIC SETTING}

\section{Geohydrologic Framework}

Marsh Creek valley is underlain by thick deposits of stratified drift of ice-contact and postice-contact fluvial and deltaic origin. Ice-contact deposits are exposed locally near the valley walls as kames, kame deltas, and kame terraces (fig. 4). Within the valley, the stratified drift is overlain by alluvial-fan deposits or flood-plain alluvium and swamp deposits. The stratified drift overlies Devonian bedrock. The upland drainage basins of the tributary streams are mantled with till and underlain by bedrock of Devonian to Pennsylvanian age (fig. 5). The geohydrologic characteristics of the postglacial and glacial deposits and bedrock are summarized in table 2 (p. 8).

\section{Bedrock Uplands}

The lower and upper slopes and ridges in the upland drainage basins of Asaph, Straight, and
Canada Runs are underlain by the Catskill and Huntley Mountain Formations, and the ridges are underlain by the Pottsville and Allegheny Groups (fig. 5). The higher ridges of the Dantz Run basin are underlain by the Huntley Mountain Formation, and the lower slopes of the Heise Run basin by the Lock Haven Formation. The remainder of the Dantz and Heise Run basins is underlain by the Catskill Formation.

In the upland drainage basins, the upper part of the bedrock is fractured and probably relatively permeable (table 2 ). Thick deposits of till and blocks of nonfractured bedrock are confining units for this shallow bedrock aquifer. In Marsh Creek valley, the bedrock was deeply eroded by glacial ice, and the more fractured rock was removed; consequently, the bedrock underlying the stratified drift is relatively impermeable. 


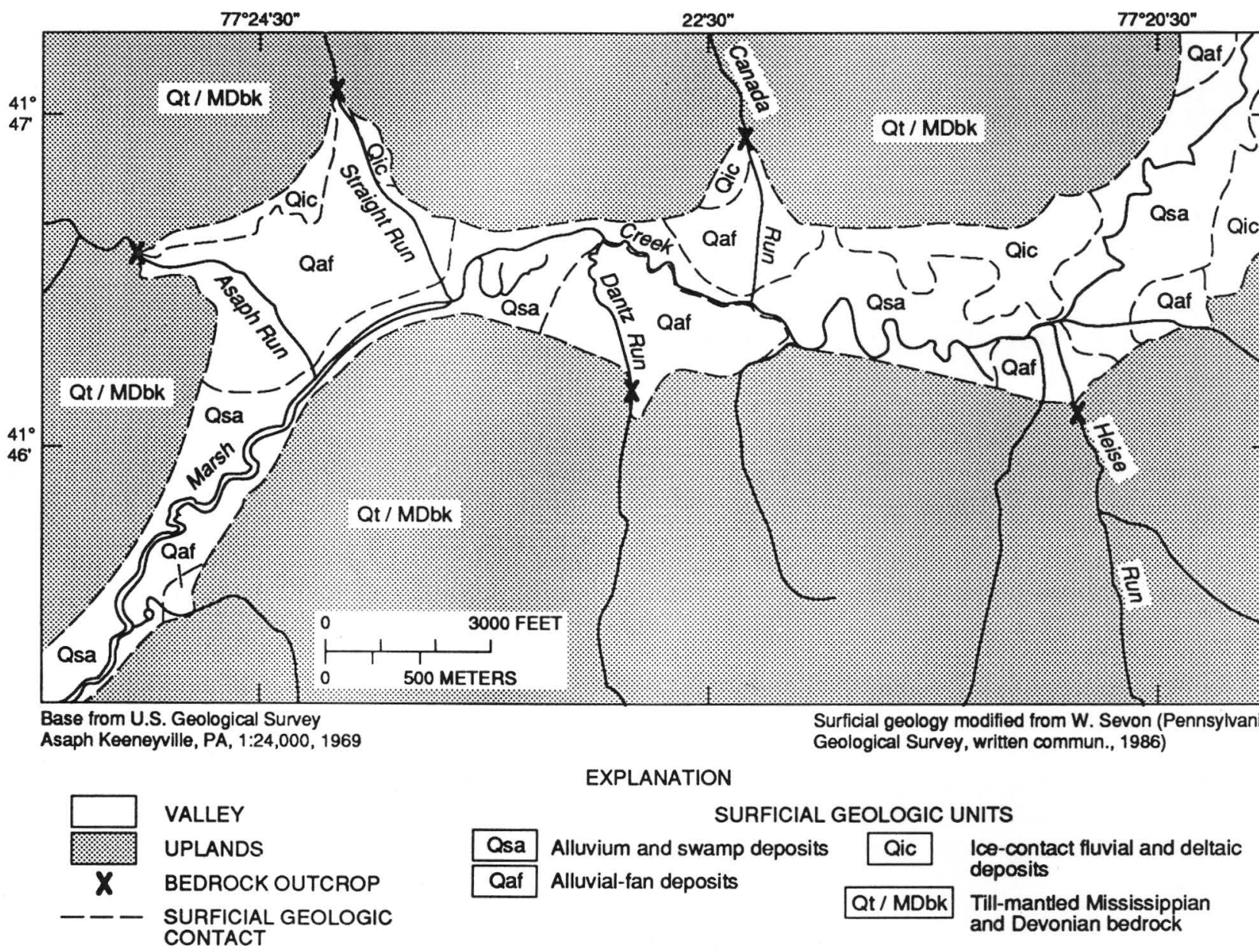

Figure 4.--Surficial geology of Marsh Creek valley.

\section{Marsh Creek Valley}

The subsurface geology near the tributary streams in Marsh Creek was interpreted from logs of wells and test holes, resistivity soundings, and a seismic-refraction line. Locations of the datacollection sites are shown in figure 6; completion information on selected wells and test holes is presented in appendix 1 . The subsurface geology along six sections is shown on plate 1 . The tributary streams are underlain by alluvial-fan deposits that are interbedded with flood-plain alluvium and swamp deposits at the margins of the fans. The postglacial deposits beneath Heise Run appear to be predominantly fine-grained alluvium and swamp deposits.

Bedrock crops out in the streambeds of the tributaries near the valley walls of Marsh Creek (fig. 4). The depth to bedrock and thickness of the stratified drift generally increase toward the center of the valley (pl. 1). The stratified drift, which consists of post-ice-contact deposits overlying ice-contact deposits, typically is from 50 to 100 feet thick. The stratified drift beneath the alluvial fans of Asaph, Straight, Canada, and Dantz Runs is predominantly coarse grained, whereas the stratified drift west and south of the alluvial fans of Asaph and Straight Runs appears to be predominantly fine grained. The stratified drift beneath Heise Run appears to be finer grained than that beneath the other tributary streams.

The streambeds of the tributaries in Marsh Creek valley are composed of loose, sandy gravel. Periodically the channels of the tributary streams are excavated by bulldozers for several hundred feet on either side of highway and railroad bridges, and the excavated streambed 


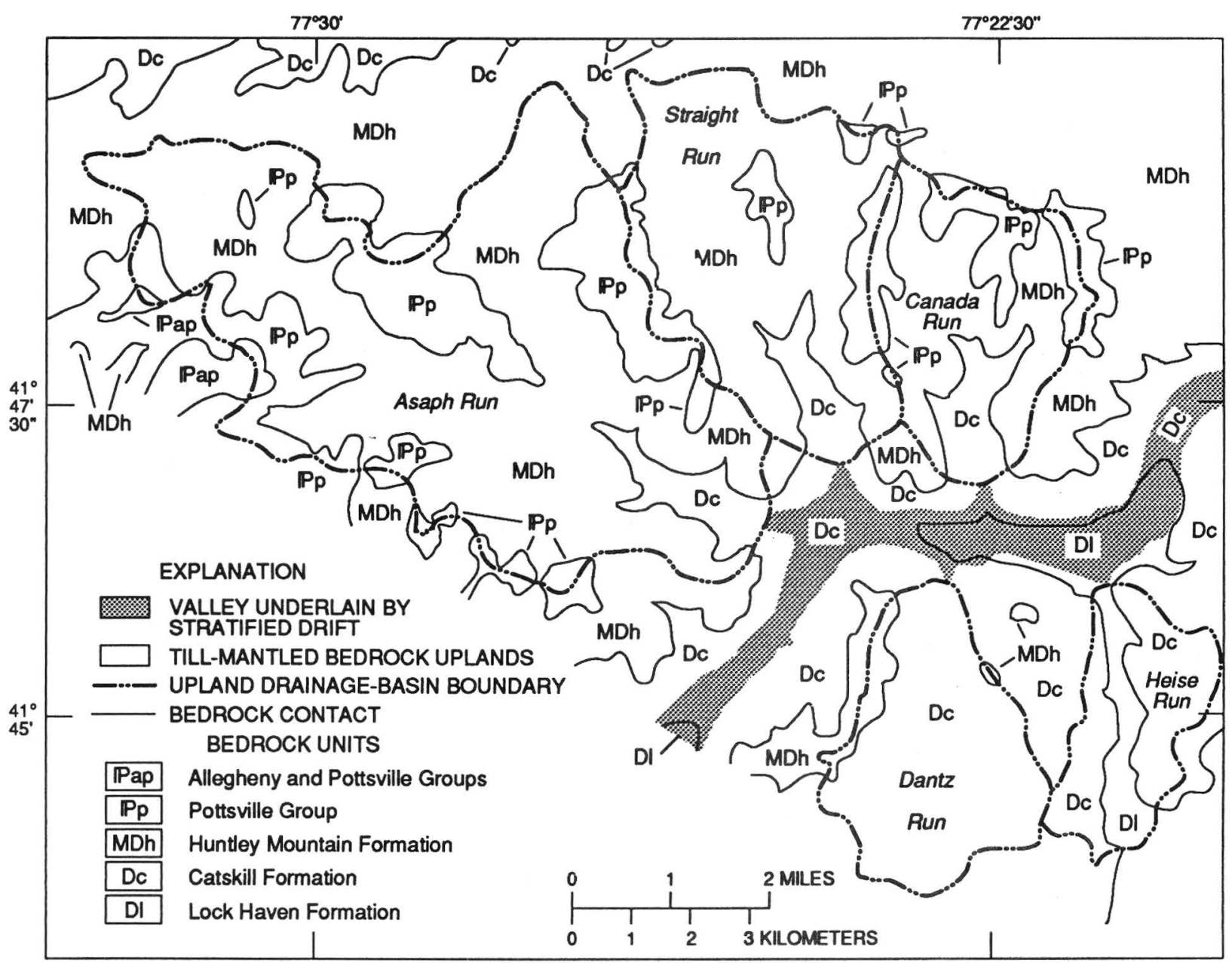

Base from U.S. Geological Survey Wellsboro, PA-NY, 1:100,000, 1981

Bedrock geology from Berg and Dodge (1981)

Figure 5.--Bedrock geology of Marsh creek valley and upland drainage basin of the tributary streams.

material is pushed up onto the streambanks to form artificial levees. The streambed of Marsh Creek consists of organic-rich silt and fine sand.

The stratified drift and overlying postglacial deposits form a complex system of aquifer and confining units (table 2). The stratified-drift aquifer is under water-table conditions near valley walls where ice-contact deposits are exposed and saturated, and near tributary streams where alluvial-fan deposits overlie coarsegrained stratified drift. Confined conditions are found beyond the margins of the alluvial fans, where flood-plain alluvium and swamp deposits commonly overlie coarse-grained stratified drift and where fine-grained stratified drift locally overlies coarse-grained stratified drift. The stratified-drift aquifer is bounded at its base and along the valley walls by till and bedrock.

The hydraulic conductivity of the stratified- drift aquifer was calculated from specificcapacity data collected at 11 wells (table 3, p. 10). The computer program of Bradbury and Rothschild (1985), which is based on a method presented by Theis and others (1963), was used for the analysis. Partial penetration of the wells is accounted for in the computer program by adjusting specific capacity by a "partialpenetration factor" as described by Brons and Marting (1961). The resulting hydraulicconductivity values are only approximate because the geohydrologic conditions do not match the required assumptions for this simple type of analysis, which are that the aquifer is isotropic, homogeneous, and extensive. An aquifer-storage coefficient of 0.2 was assumed, and well losses were not considered in the analysis. Completion information on the wells is presented in appendix 1; locations of the wells are shown in 
Table 2.--Geohydrologic characteristics of the postglacial and glacial deposits and bedrock.

\begin{tabular}{|c|c|c|c|c|}
\hline Age & Geologic Unit & Lithology & Distribution and Thickness & Hydrology \\
\hline \multicolumn{5}{|c|}{ POSTGLACIAL DEPOSITS } \\
\hline \multirow{6}{*}{ 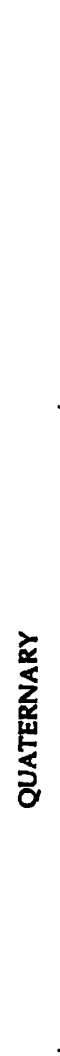 } & $\begin{array}{l}\text { Alluvium and } \\
\text { swamp } \\
\text { deposits }\end{array}$ & $\begin{array}{l}\text { Silt and fine sand with } \\
\text { organic-rich layers. }\end{array}$ & $\begin{array}{l}\text { Flood plain of Marsh Creek } \\
\text { and other low-lying areas; } \\
\text { about } 20 \text { feet thick. }\end{array}$ & $\begin{array}{l}\text { Surficial confining unit; } \\
\text { upward leakage from } \\
\text { stratified-drift aquifer } \\
\text { discharges to Marsh Creek or } \\
\text { is lost as evapotranspiration. }\end{array}$ \\
\hline & $\begin{array}{l}\text { Alluvial-fan } \\
\text { deposits }\end{array}$ & $\begin{array}{l}\text { Silty sand and gravel } \\
\text { with some organic } \\
\text { matter. }\end{array}$ & $\begin{array}{l}\text { Alluvial fans of the tributary } \\
\text { streams in Marsh Creek } \\
\text { valley; about } 15 \text { to } 30 \text { feet } \\
\text { thick. }\end{array}$ & $\begin{array}{l}\text { Part of stratified-drift aquifer } \\
\text { where saturated; infiltration } \\
\text { from direct precipitation and } \\
\text { tributary streams recharges } \\
\text { underlying stratified drift. }\end{array}$ \\
\hline & $\overline{\text { RATIFIED DRI }}$ & & & \multirow{4}{*}{$\begin{array}{l}\text { Part of stratified-drift aquifer } \\
\text { where saturated; finer } \\
\text { grained beds are } \\
\text { discontinuous confining units }\end{array}$} \\
\hline & $\begin{array}{l}\text { Post-ice- } \\
\text { contact fluvial } \\
\text { and deltaic } \\
\text { deposits }\end{array}$ & $\begin{array}{l}\text { Variably silty sand and } \\
\text { gravel interbedded with } \\
\text { silt and sand; most } \\
\text { grains appear to be } \\
\text { sandstone and shale of } \\
\text { local origin. }\end{array}$ & $\begin{array}{l}\text { Buried beneath postglacial } \\
\text { deposits within Marsh } \\
\text { Creek valley; typical } \\
\text { maximum thickness is } \\
\text { about } 50 \text { feet. }\end{array}$ & \\
\hline & \multirow{2}{*}{$\begin{array}{l}\text { Ice-contact } \\
\text { fluvial and } \\
\text { deltaic } \\
\text { deposits }\end{array}$} & $\begin{array}{l}\text { Variably silty sand and } \\
\text { gravel interbedded with } \\
\text { silt and sand; contains }\end{array}$ & \multirow{2}{*}{$\begin{array}{l}\text { Locally exposed near the } \\
\text { walls of Marsh Creek valley } \\
\text { as kames, kames deltas, and } \\
\text { kame terraces and buried } \\
\text { beneath post-ice-contact } \\
\text { and postglacial deposits } \\
\text { within Marsh Creek valley; } \\
\text { typical maximum thickness } \\
\text { is about } 50 \text { feet. }\end{array}$} & \\
\hline & & $\begin{array}{l}\text { some limestone and } \\
\text { other calcareous } \\
\text { pebbles not of local } \\
\text { origin; may show } \\
\text { collapsed features. }\end{array}$ & & \\
\hline & & & & \\
\hline \multirow{4}{*}{ 孞 } & & $\begin{array}{l}\text { Unsorted mixture of } \\
\text { clay- to boulder-sized } \\
\text { material; compact. }\end{array}$ & $\begin{array}{l}\text { Mantles bedrock in the } \\
\text { uplands; locally may overlie } \\
\text { bedrock in Marsh Creek } \\
\text { valley; typically less than } 10 \\
\text { feet thick. }\end{array}$ & $\begin{array}{l}\text { Part of basal and lateral } \\
\text { boundary of stratified-drift } \\
\text { aquifer; surficial confining } \\
\text { unit of shallow bedrock } \\
\text { aquifer in uplands. }\end{array}$ \\
\hline & DROCK & & & \multirow{4}{*}{$\begin{array}{l}\text { Shallow bedrock aquifer in } \\
\text { uplands. }\end{array}$} \\
\hline & $\begin{array}{l}\text { Allegheny } \\
\text { Group }\end{array}$ & $\begin{array}{l}\text { Sandstone, shale and } \\
\text { coalbeds }\end{array}$ & High upland ridges & \\
\hline & $\begin{array}{l}\text { Pottsville } \\
\text { Group }\end{array}$ & $\begin{array}{l}\text { Sandstone and } \\
\text { conglomerate with } \\
\text { some thin coal beds; } \\
\text { fluvial. }\end{array}$ & $\begin{array}{l}\text { High upland ridges; about } \\
150 \text { feet thick. }\end{array}$ & \\
\hline \multirow{2}{*}{ 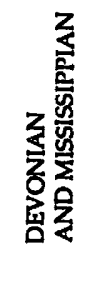 } & $\begin{array}{l}\text { Huntley } \\
\text { Mountain } \\
\text { Formation }\end{array}$ & $\begin{array}{l}\text { Sandstone with some } \\
\text { shale; fluvial }\end{array}$ & $\begin{array}{l}\text { Upper slopes and some } \\
\text { ridges in the uplands; about } \\
650 \text { feet thick. }\end{array}$ & \\
\hline & $\begin{array}{l}\text { Catskill } \\
\text { Formation }\end{array}$ & $\begin{array}{l}\text { Sandstone and shale; } \\
\text { shale; deltaic }\end{array}$ & $\begin{array}{l}\text { Slopes and some low ridges } \\
\text { in the uplands and part of } \\
\text { Marsh Creek valley; about } \\
500 \text { feet. }\end{array}$ & \multirow{2}{*}{$\begin{array}{l}\text { Shallow bedrock aquifer in } \\
\text { uplands; part of basal and } \\
\text { lateral boundary of stratified- } \\
\text { drift aquifer in Marsh Creek } \\
\text { valley. }\end{array}$} \\
\hline 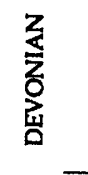 & $\begin{array}{l}\text { Lock Haven } \\
\text { Formation }\end{array}$ & $\begin{array}{l}\text { Shale and sandstone; } \\
\text { marine; contains some } \\
\text { calcareous beds. }\end{array}$ & $\begin{array}{l}\text { Part of Marsh Creek valley } \\
\text { and the lower slope of the } \\
\text { Heise Run basin; about } \\
\text { 3,000 feet thick. }\end{array}$ & \\
\hline
\end{tabular}



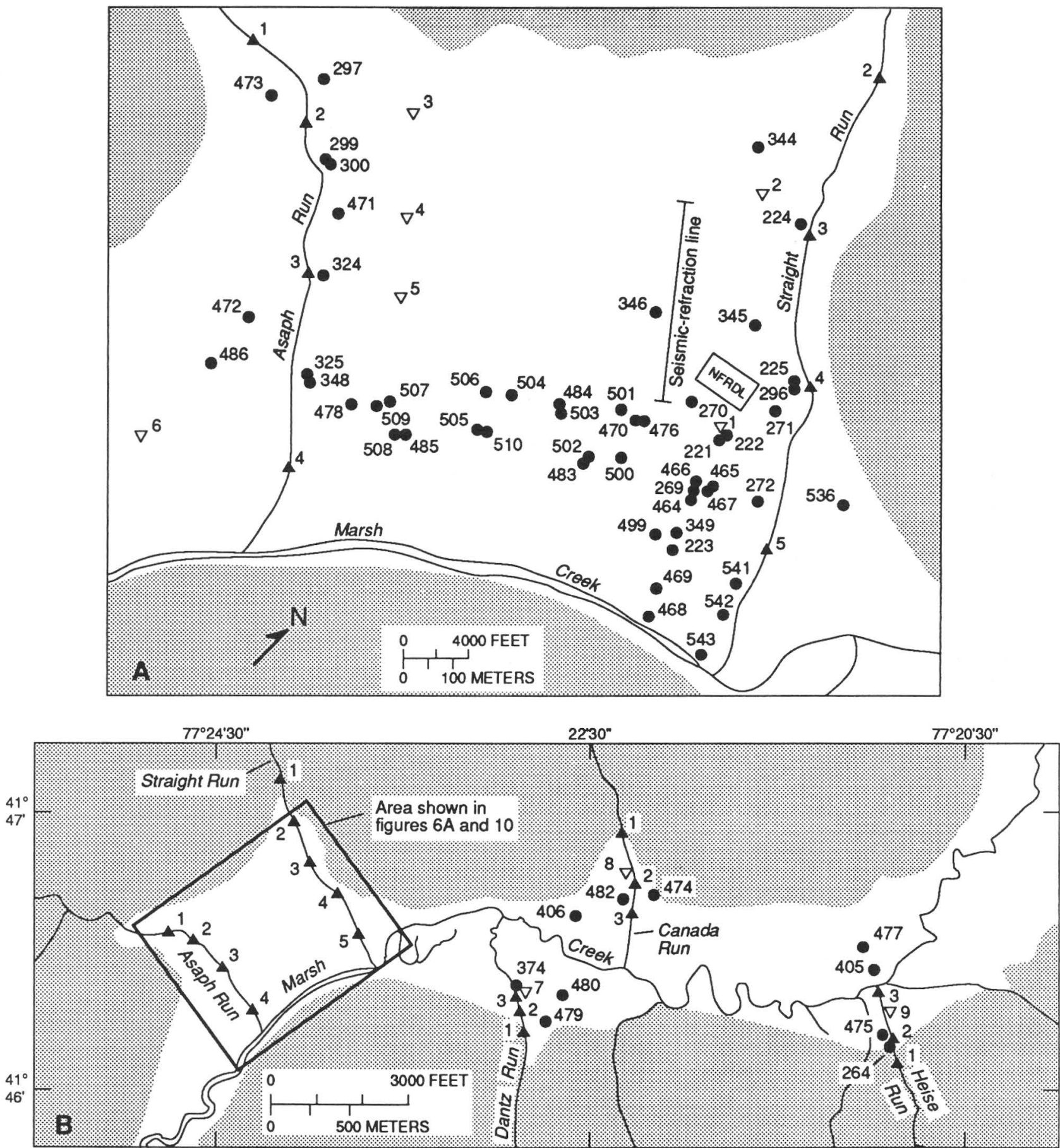

Base from U.S. Geological Survey

Asaph Keeneyville, PA, 1:24,000, 1969

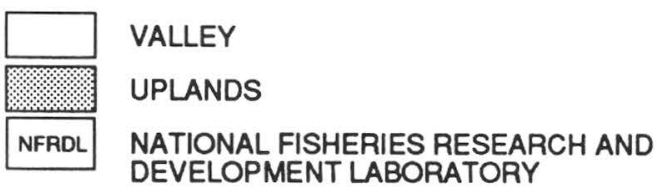

EXPLANATION

Figure 6.--Location of data-collection sites: A. near Asaph and Straight Runs. B. throughout study area 
Table 3.-Summary of selected specific-capacity tests in the stratified-drift aquifer near Straight and Asaph Runs

\begin{tabular}{cccccc}
\hline Tested well & Date of test & $\begin{array}{c}\text { Length of test, } \\
\text { in hours }\end{array}$ & $\begin{array}{c}\text { Saturated } \\
\text { thickness, } \\
\text { in feet }\end{array}$ & $\begin{array}{c}\text { Specific } \\
\text { capacity, in } \\
\text { gallons per } \\
\text { minute per } \\
\text { foot of } \\
\text { drawdown }\end{array}$ & $\begin{array}{c}\text { Estimated } \\
\text { hydraulic } \\
\text { conductivity, } \\
\text { in feet per day }\end{array}$ \\
\hline 222 & $09 / 73$ & 3 & 90 & 40 & 250 \\
$223,468,469$ & $08 / 73$ & 1 & 60 & $10^{\mathrm{a}}$ & 38 \\
269 & $09 / 77$ & 29 & 90 & 34 & 260 \\
270 & $10 / 77$ & 9 & 85 & 21 & 130 \\
271 & $10 / 77$ & 24 & 90 & 27 & 250 \\
272 & $11 / 77$ & 8 & 80 & 24 & 190 \\
467 & $11 / 73$ & 6 & 100 & 33 & 200 \\
470 & $11 / 85$ & 0.3 & 60 & 5.0 & 120 \\
471 & $11 / 85$ & 1 & 30 & 16 & 330 \\
\hline & & & & & \\
\end{tabular}

a Average based on range of reported drawdowns.

figure 6. Ten of the tested wells are near Straight Run, the other is near Asaph Run. Estimates of hydraulic conductivity for the aquifer range from 38 to 330 feet per day (ft/d) and average $200 \mathrm{ft} / \mathrm{d}$.

\section{Hydrologic System}

\section{Bedrock Uplands}

The bedrock aquifer in the uplands is recharged by infiltration of precipitation through the overlying till. Ground water flows in the bedrock aquifer toward topographic lows and discharges to the tributary streams. Along the valley walls of Marsh Creek, some ground water flows from the bedrock uplands to the stratifieddrift aquifer.

Tributary streamflow from the bedrock uplands consists of surface runoff and groundwater discharge. Streamflow typically peaks within a day after storms; after several days, surface runoff becomes negligible and streamflow consists entirely of ground-water discharge. Hydrographs of streamflow in Asaph and Straight Runs near the valley wall of Marsh Creek during water year 1985 are presented in figure 7 , which also includes estimated daily precipitation in the study area. The precipitation data were interpolated from information collected at the National Weather
Service stations at Wellsboro and Galeton, 5 miles southeast and 12 miles west of the study area, respectively (National Oceanic and Atmospheric Administration, 1985). Estimated precipitation for water year 1985 was 30.1 inches, which is 4.8 inches less than the estimated long-term average. The hydrographs generally show the typical seasonal trends in tributary flow; streamflow increases in late fall and early winter as evapotranspiration decreases at the end of the growing season. During December 1984, flow in Asaph and Straight Runs averaged 39 and $19 \mathrm{ft}^{3} / \mathrm{s}$, respectively. During the winter freeze, streamflow decreases from the lack of surface runoff and ground-water recharge. In early February 1985, flow in Asaph and Straight Runs reached lows of 3.1 and $1.8 \mathrm{ft}^{3} / \mathrm{s}$, respectively.

In the early spring, evapotranspiration is low, and rains and snowmelt significantly increase streamflow. During March 1985, flow in Asaph and Straight Runs averaged 39 and $18 \mathrm{ft}^{3} / \mathrm{s}$, respectively. At the start of the growing season, streamflow decreases as evapotranspiration increases. The decrease of flow in Asaph and Straight Runs during April 1985 was greater than normal because precipitation for the month had been lower than average. Streamflow continues to decrease through the summer (although thunderstorms cause sharp peaks in streamflow) and reaches a minimum in late summer or early fall. In mid- to late August 1985, flow in Asaph 
and Straight Runs reached lows of 0.85 and 0.47 $\mathrm{ft}^{3} / \mathrm{s}$, respectively.

The average streamflow in Asaph and Straight Runs for water year 1985 was 16 and 7.0 $\mathrm{ft}^{3} / \mathrm{s}$, respectively, or about 13 inches of runoff from the upland drainage basins. Assuming no net change in surface- or ground-water storage in water year 1985, the difference between precipitation and runoff from the basins, about 17 inches, was water lost through evapotranspiration. The amount of evapotranspiration was minimal in winter and early spring and at a maximum in summer and early fall. Streamflow data from Asaph and Straight Run basins indicate that evapotranspiration during March and August 1985 ( 2 months that appeared to have minimal net change in storage, as indicated by ground-water levels in Marsh Creek valley that are not affected by pumping) was less than 10 percent and greater than 90 percent, respectively.

\section{Marsh Creek Valley}

The stratified-drift aquifer in Marsh Creek valley is recharged by (1) direct infiltration of precipitation in areas underlain by alluvial-fan
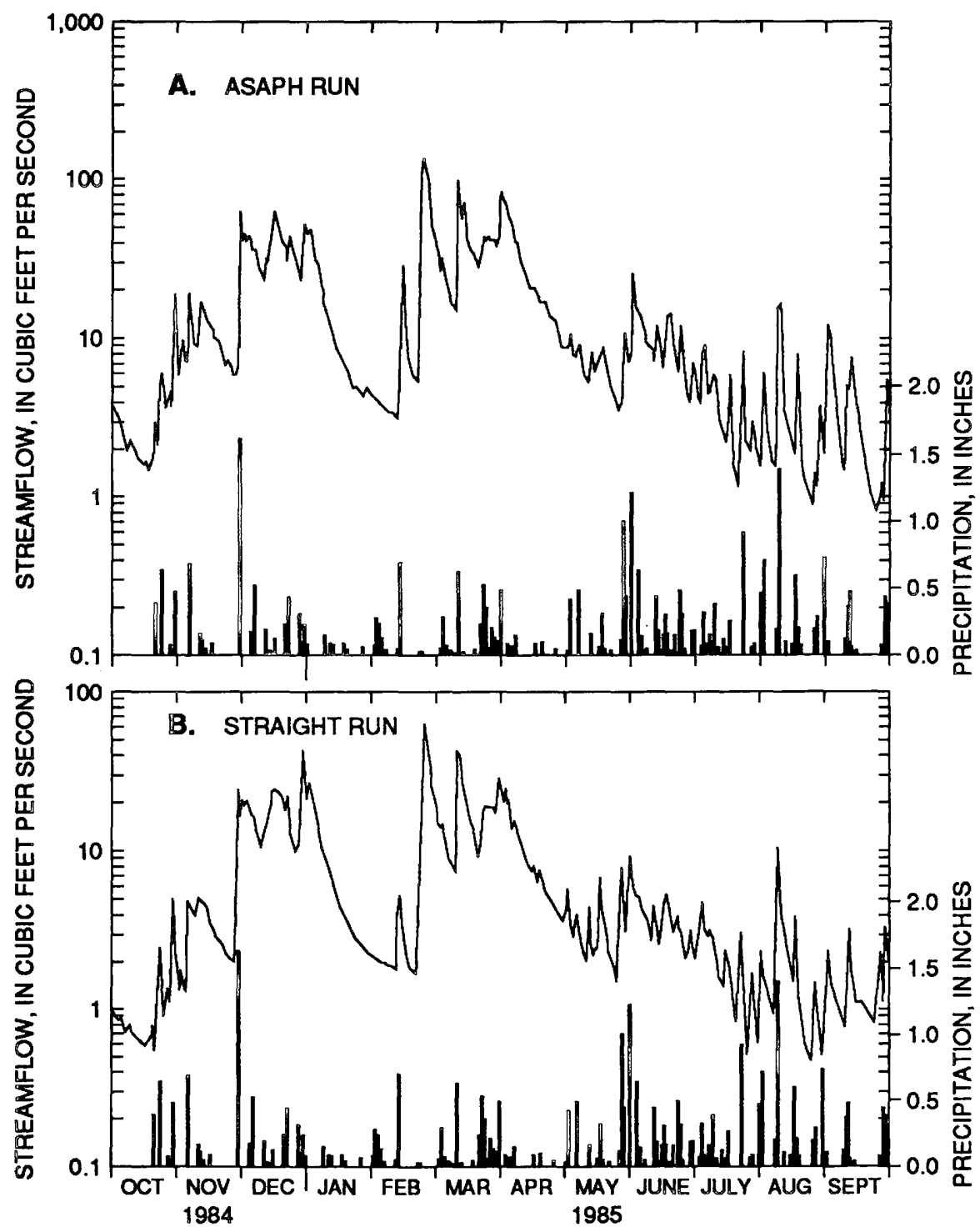

Figure 7.--Streamflow from the upland drainage basins of Asaph and Straight Runs and estimated precipitation, water year 1985. 
and valley-wall, ice-contact deposits, and, to a much lesser extent, fine-grained alluvium and swamp deposits; (2) infiltration from tributary streams that drain the uplands; and (3) groundwater inflow and infiltration at the valley walls of unchanneled runoff from small areas of upland not drained by tributary streams. Infiltration induced from Marsh Creek and swamps by pumping at the National Fisheries Research and Development Laboratory wellfield is probably minimal because these areas are underlain by 10 to 15 feet of fine-grained alluvium and swamp deposits (pl. 1, section C-C'). In addition, south of the alluvial fan of Straight Run near Marsh Creek, the stratified drift appears to be finer grained and less permeable. Some of the ground water from the alluvial-fan and valley-wall areas flows beneath fine-grained postglacial or stratified-drift deposits and recharges the confined system. Ground water discharges from the stratified-drift aquifer by lateral flow or slow upward leakage to Marsh Creek and swamps, through evapotranspiration in swampy areas, and through ground-water pumping.

The only major ground-water withdrawal in the study area is the pumping at the National Fisheries Research and Development Laboratory wellfield. The wellfield contains three production wells that supply research facilities and one well for domestic use. The wells are 80 to 95 feet deep and are completed in the stratifieddrift aquifer. Locations of the wells are shown in figure 6; completion information is given in appendix 1. After use in the research facility, the water pumped from the production wells is discharged to Marsh Creek 500 feet downstream of the mouth of Straight Run. Almost all water pumped by the domestic well is returned to the ground by a septic system. Other ground-water pumping in the study area is for domestic and minor stock and irrigation use by private homes and small farms. The domestic water systems include dug, driven, and drilled wells. The wells are completed in alluvial-fan deposits, stratified drift, or bedrock. Completion information on selected domestic wells is given in appendix 1; their locations are shown in figure 6. Almost all of the water pumped from the domestic wells is returned to the ground by septic systems.

The pumping rate from the production wells at the National Fisheries Research and Development Laboratory from the opening of the research facility in October 1978 through September 1983 was about $0.5 \mathrm{ft}^{3} / \mathrm{s}$. In October
1983 , the rate was increased to $2.4 \mathrm{ft}^{3} / \mathrm{s}$ but subsequently was reduced to $0.5 \mathrm{ft}^{3} / \mathrm{s}$ when three nearby homeowners reported decreased yield from their shallow domestic wells. The pumping rate gradually increased throughout the rest of the water year and, by September 1984, was 1.3 $\mathrm{ft}^{3} / \mathrm{s}$. During water year 1985, the rate increased in successive steps to $3.2 \mathrm{ft}^{3} / \mathrm{s}$ or more in September of 1985 (fig. 8). Between August and November

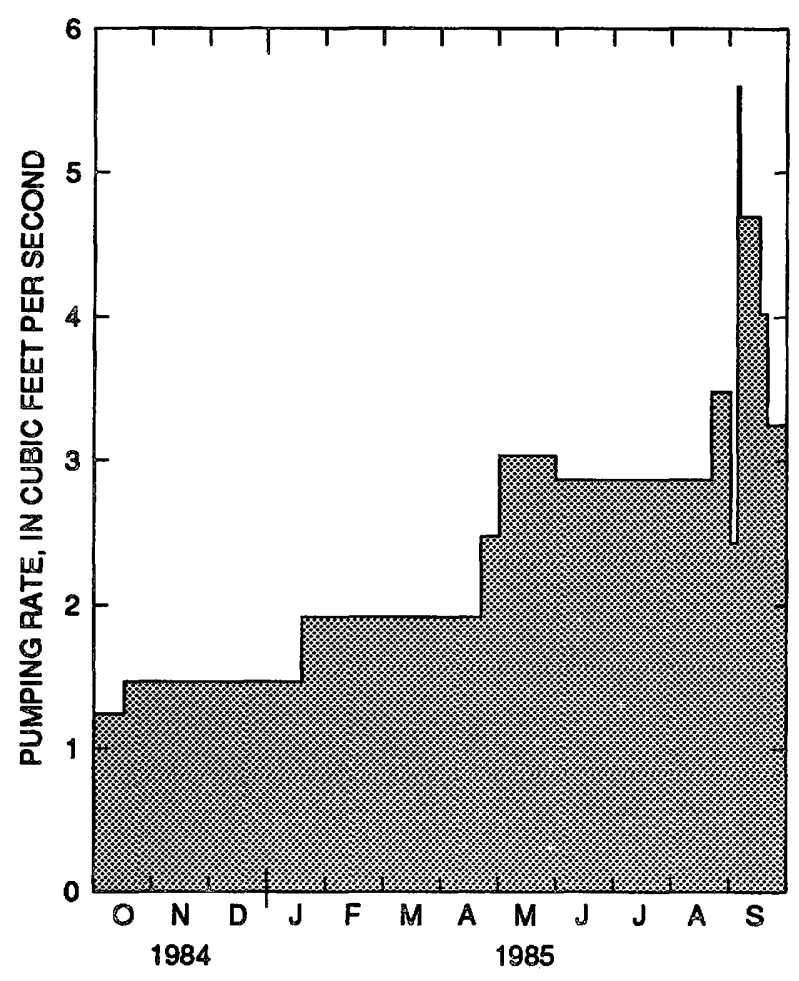

Figure 8.--Pumping rate at the National Fisheries Research and Development Laboratory wellfield, water year 1985.

1985, the domestic well of the National Fisheries Research and Development Laboratory supplied water to 10 nearby homeowners whose domestic well yields may have been decreased by the increased pumpage. As part of two aquifer tests at the National Fisheries Research and Development Laboratory wellfield, the pumping rate was increased during September 5-20, 1985. Purnpage was $5.8 \mathrm{ft}^{3} / \mathrm{s}$ on September $5,4.7 \mathrm{ft}^{3} / \mathrm{s}$ during September 6-15, and $4.0 \mathrm{ft}^{3} / \mathrm{s}$ during September 16-20. During September 16-20, 1.6 $\mathrm{ft}^{3} / \mathrm{s}$ of the pumped water was not discharged to Marsh Creek but to Straight Run, 1,500 feet 
upstream of the wellfield. In November 1985, in response to results of the aquifer tests, the U.S. Fish and Wildlife Service replaced 11 shallow domestic wells near the National Fisheries Research and Development Laboratory with drilled wells 75 to 95 feet deep.

The water table in the stratified-drift aquifer fluctuates with recharge and discharge. Hydrographs of water levels measured in wells 470 and 471 during water year 1985 are presented in figure 9. Well 470 is near Straight Run, and well 471 is near Asaph Run (fig. 6). The hydrograph from well 471 shows the typical seasonal trends in water levels in the stratifieddrift aquifer. Ground-water levels rise in late fall and early winter as evapotranspiration decreases at the end of the growing season, then stabilize or decline somewhat during the winter freeze as a result of decreased recharge, and then rise during the spring thaw with the increased recharge from infiltration of rain, snowmelt, overland runoff, and tributary streamflow. In late spring, ground-water levels decline as high evapotranspiration at the start of the growing season causes recharge to decrease. Ground-water levels continue to decline through the summer and reach their lowest levels in late summer and early fall. In water year 1985, the water-level fluctuation in well 471 was 7 feet; the highest levels occurred in early winter and spring and the lowest levels in late summer. During the summer of 1985, the water level in well 471 fluctuated rapidly in response to increases and decreases in infiltration from Asaph Run as streamflow varied.
Pumping from the National Fisheries Research and Development Laboratory wellfield significantly lowered the water level in well 470 during water year 1985. The increase in pumpage between April and September 1985 (fig. 8) accentuated the natural water-level decline, and the water level in the well dropped about 20 feet during that time.

Water levels in selected wells completed in the stratified-drift aquifer near Straight and Asaph Runs on selected dates during water year 1985 are presented in figure 10. Ground-water levels near Asaph Run and the upper part of Straight Run rose 1.3 to 5.8 feet between October 10, 1984 and March 30, 1985, reflecting the increased recharge during the spring thaw. The 6.1- to 46-foot drop in water levels between October 10, 1984 and September 8, 1985 near the lower part of Straight Run is largely due to the increased pumping at the National Fisheries Research and Development Laboratory wellfield.

Average water levels for the month of October from 1935 through 1985 in well 1 are presented in figure 11. Well 1 is near Long Run, a tributary to Pine Creek at Gaines, 8 miles west of the study area. The well is 23 feet deep and completed in alluvial-fan deposits in a geohydrologic setting similar to the study area. October levels are generally representative of low-water conditions for the year and reflect annual variations in recharge. The hydrograph indicates that the average water levels for October 1983, 1984, and 1985 were significantly below normal. The lowest average October level was in 1964 as a result of the early 1960's drought.
Figure 9.

Water levels in well 470 near Straight Run and well 471 near Asaph Run, water year 1985.

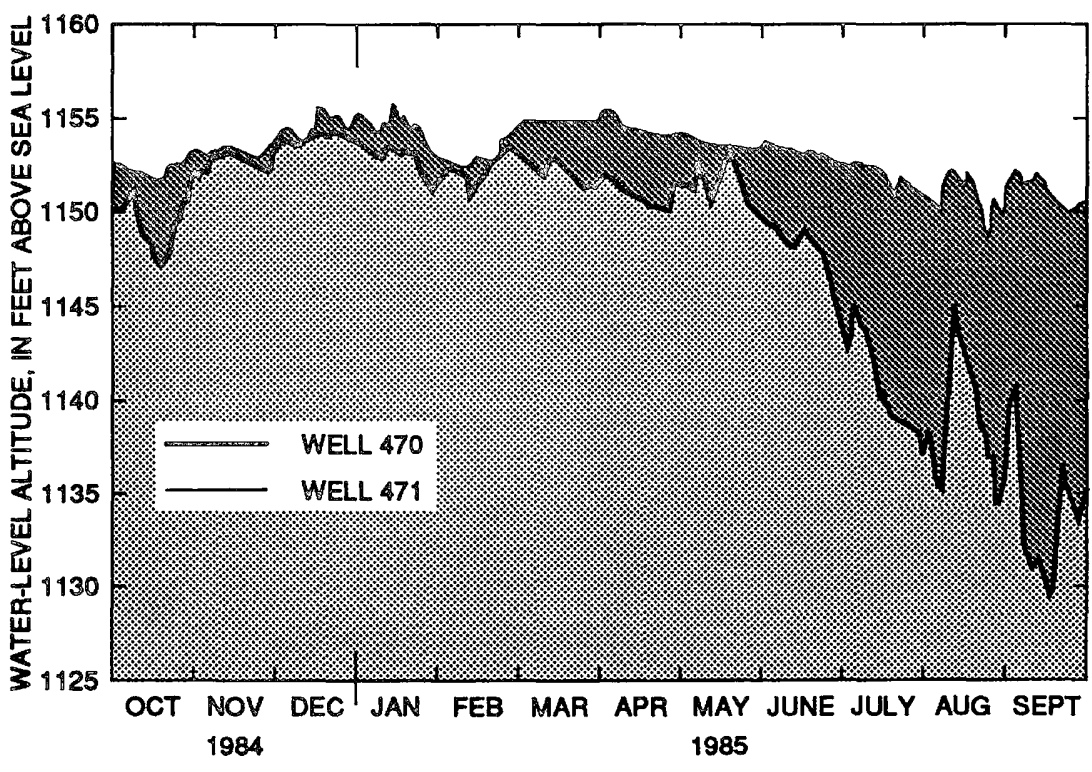




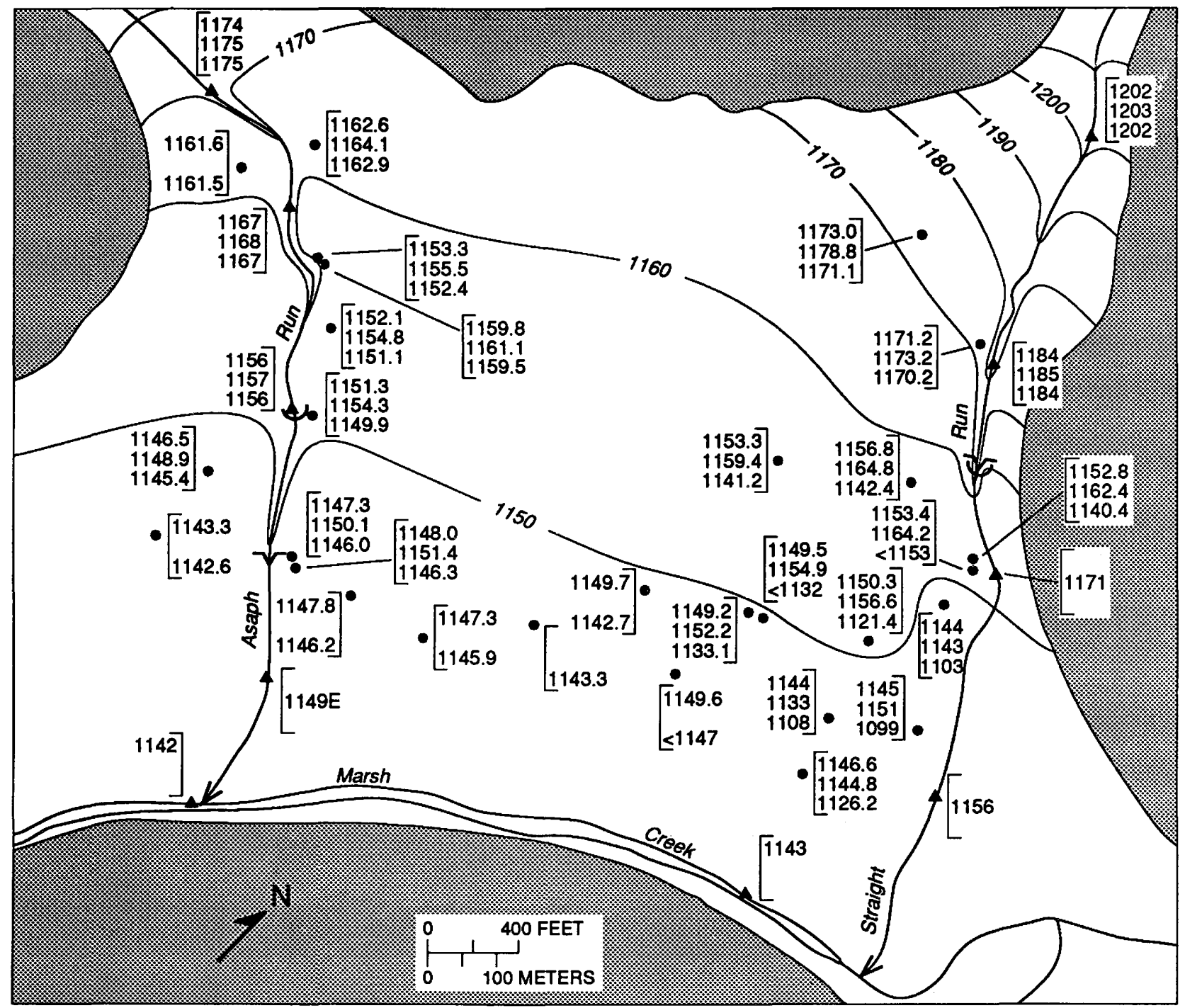

Base from U.S. Geological Survey

Asaph Keeneyville, PA, 1:24,000, 1969

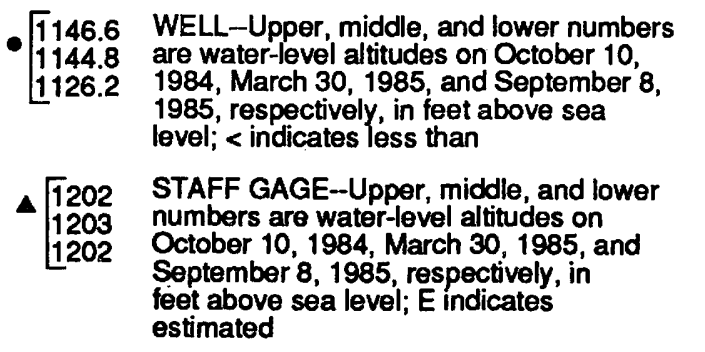

EXPLANATION

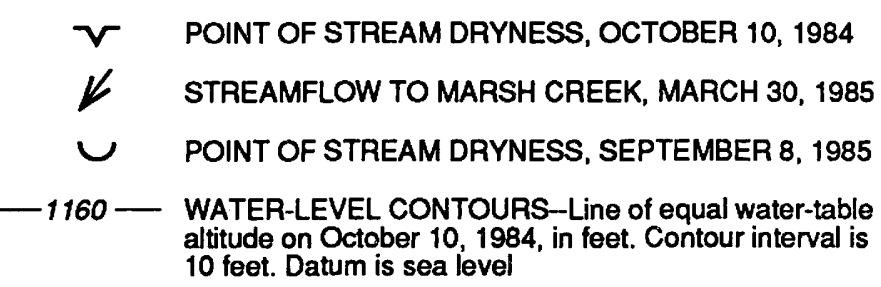

eet above sea level; $E$ indicates 10 feet. Datum is sea level

Figure 10.--Water levels in selected wells and at staff gages near Asaph and Straight Runs; October 10, 1984; March 30, 1985; and September 8, 1985. 


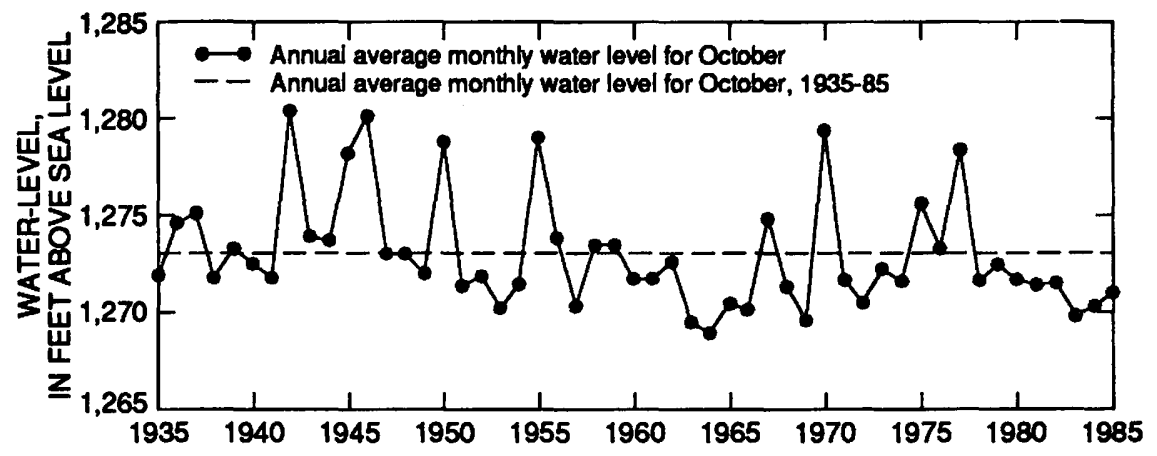

Figure 11.

Average water levels for October in well 1 near Long Run, 8 miles west of the study area, 1935-85.

\section{Water Quality}

Water from the tributary streams and the stratified-drift aquifer contains calcium and bicarbonate as the major cation and anion, respectively, and is relatively low in dissolved solids. In contrast, water from restricted-flow zones in the bedrock underlying Marsh Creek valley is characterized as sodium-chloride type and is high in total dissolved solids. The results of field analyses of specific conductance and hardness for water samples from selected streams and well sites is presented in table 4. Total dissolved-solids concentration, in milligrams per liter (mg/L), was estimated from specific conduc- tance, in microsiemens per centimeter at 25 degrees Celsius $(\mu \mathrm{S} / \mathrm{cm})$ by multiplying the latter by 0.6 (Taylor and others, 1983). Most of the samples were collected during the fall of 1985 and repeated field analyses at selected sites showed minimal seasonal variation.

Water from Asaph, Straight, and Canada Runs near the valley walls had low specific conductance (less than $75 \mu \mathrm{S} / \mathrm{cm}$ ) and was soft, as were samples from wells completed in the stratified-drift aquifer near Asaph and Straight Runs. Water from well 486, near Asaph Run, which is completed in bedrock, had a specific conductance of more than $1,000 \mu \mathrm{S} / \mathrm{cm}$ and was

Table 4.--Specific conductance and hardness of water sampled at selected streams and well sites.

[Stream and well locations shown in fig. 6.]

\begin{tabular}{cccc} 
& Specific & \\
Source & $\begin{array}{c}\text { Casing depth, } \\
\text { in feet }\end{array}$ & $\begin{array}{c}\text { conductance, in } \\
\text { microsiemens per } \\
\text { centimeter }\end{array}$ & $\begin{array}{c}\text { Total hardness as } \\
\mathrm{CaCO}_{3} \text { in } \\
\text { milligrams per liter }\end{array}$ \\
\hline
\end{tabular}

Tributary stream sampled near valley wall

$\begin{array}{llrl}\text { Asaph } & - & 60 & 20 \\ \text { Straight Run } & - & 70 & 30 \\ \text { Dantz Run } & - & 140 & 70 \\ \text { Canada Run } & - & 60 & 30 \\ \text { Heise Run } & - & 160 & 70\end{array}$

Well completed in stratified-drift aquifer

$\begin{array}{lrrr}470 & 69 & 90 & 30 \\ 485 & 15 & 60 & 30 \\ 504 & 89 & 110 & 50 \\ 505 & 73 & 65 & 30 \\ 506 & 72 & 60 & 30 \\ 508 & 71 & 60 & 30\end{array}$

Well completed in bedrock 486

122

1,100

100 
hard. The dissolved-solids concentration of the sample indicates the presence of some highly mineralized water from a restricted flow zone in the bedrock. A sample from a restricted-flow zone in bedrock that was penetrated by well 498 in Marsh Creek valley, 5 miles east of the study area, had a dissolved-solids concentration of $7,800 \mathrm{mg} / \mathrm{L}$.

Water from Dantz and Heise Runs had specific conductances of 140 to $160 \mu \mathrm{S} / \mathrm{cm}$ and was moderately hard, presumably because the drainage basins of these streams are almost totally underlain by Devonian bedrock, which is more calcareous than the Mississippian and
Pennsylvanian bedrock that underlies much of the Asaph, Straight, and Canada Run basins (fig. 5).

Diagrams of the major cation and anion concentrations in representative waters are presented in figure 12. The major cation in the stratified-drift aquifer and tributary streams is calcium; the major anion is bicarbonate. The major cation and anion in samples that contain water from restricted-flow zones in the bedrock are sodium and chloride. Water from well 486 contained $175 \mathrm{mg} / \mathrm{L}$ sodium and $300 \mathrm{mg} / \mathrm{L}$ chloride, and water from the restricted-flow zone penetrated by well 498 contained $2,500 \mathrm{mg} / \mathrm{L}$ sodium and $4,600 \mathrm{mg} / \mathrm{L}$ chloride.
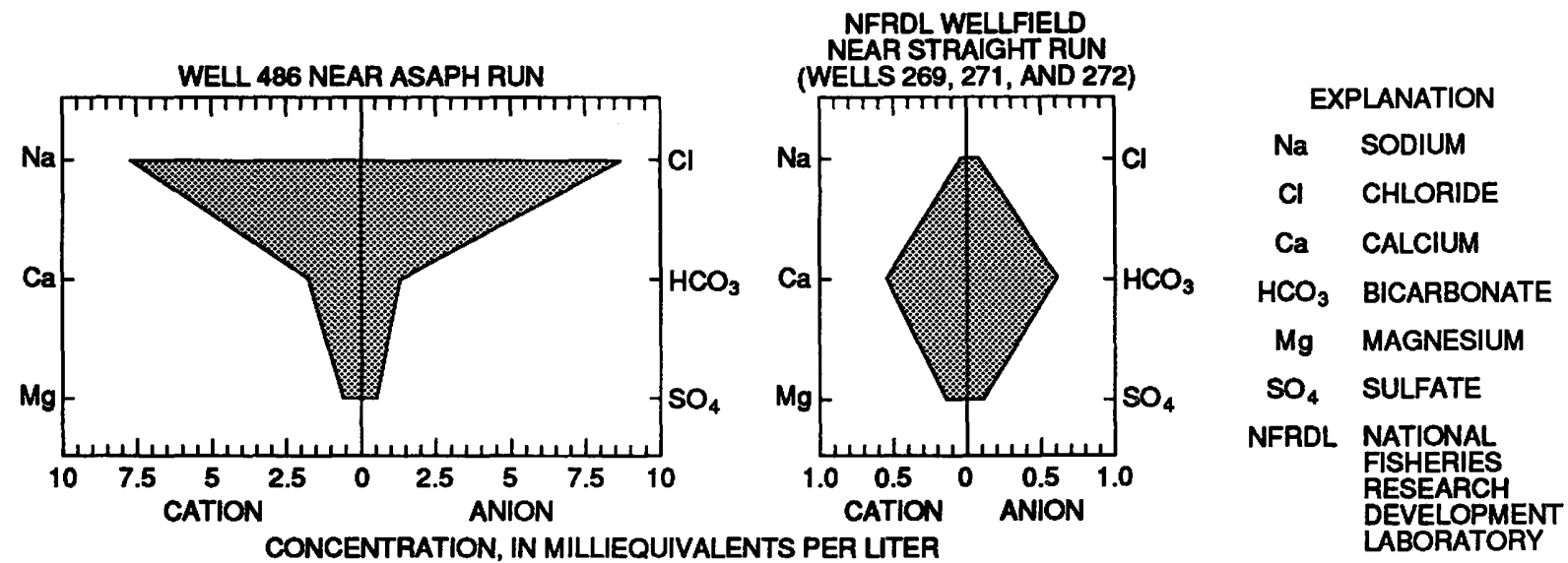

Figure 12.--Major cation and anion concentrations in water sampled at selected well sites. [Locations are shown in fig. 6.].

\section{STREAM INFILTRATION}

\section{Infiltration Rates}

Streamflow measurements were made at selected sites along the tributary streams in Marsh Creek valley to determine rates of stream infiltration (appendix 2). Locations of the stream-measurement sites are shown in figure 6. The change in discharge between measurement sites was calculated from the streamflow measurements and is considered to represent infiltration to or from the stream reach. When a tributary stream went dry before reaching Marsh Creek, the point of stream dryness (point at which cumulative stream loss equals total streamflow) was recorded. Asaph, Straight, Dantz, and Canada Runs had significant losses along the reaches measured, whereas Heise Run had minimal losses or small gains in streamflow.
Streamflow measurements were made under a range of flow conditions. At the time of the discharge measurements, streamflow at the upstream sites along Asaph Run ranged from 2.04 to $73.8 \mathrm{ft}^{3} / \mathrm{s}$, Straight Run from 0.74 to $32.8 \mathrm{ft}^{3} / \mathrm{s}$, Dantz Run from 0.71 to $5.78 \mathrm{ft}^{3} / \mathrm{s}$, Canada Run from 0.91 to $7.38 \mathrm{ft}^{3} / \mathrm{s}$, and Heise Run from 0.29 to 1.66 $\mathrm{ft}^{3} / \mathrm{s}$. In general, the measurement conditions were rated as "good," which indicates that the discharges are assumed to be accurate within 5 percent. Thus, the potential error in the calculated infiltration between sites is as high as 10 percent of the average of the two measured discharges. As discharge increases, infiltration becomes a smaller percentage of the discharge, so that at higher flows the potential error is significantly greater than the calculated infiltration. 
Cumulative infiltration along the streams is presented in figure 13, and stream infiltration rates per 1,000 feet of wetted channel length are presented in table 5 . In losing streams, an upstream reach of relatively small and (or) erratic losses was followed by a downstream reach of consistently large losses. A similar phenomenon was observed by Randall (1978) along tributary streams in the Susquehanna River basin of New York.

One set of preliminary measurements indicated that losses from Asaph Run were minimal between site 1 and a site at the farthest downstream bedrock outcrop 1,000 feet upstream; therefore that reach was not measured again. The reach between sites 1 and 2 on Asaph Run was estimated to have significant losses at low to medium streamflow but significant gains during high flows. These gains may result from discharge of abundant upland runoff, which recharges the stratified-drift aquifer during and shortly after periods of rain or snowmelt, and (or) discharge of bank storage after high streamflows. Water from upland runoff or bank storage may be discharged to the stream because the aquifer is relatively narrow and thin in that reach and thus restricts the amount of recharge that can move downward and laterally to Marsh Creek. Alternatively, these gains may be spurious-the result of large measurement errors at high flows. Stream loss along Asaph Run between sites 2 and 4 averaged $1.9 \mathrm{ft}^{3} / \mathrm{s}$ per 1,000 feet of wetted channel length. Stream loss along Straight Run between sites 1 and 3 averaged about $0.28 \mathrm{ft}^{3} / \mathrm{s}$ per 1,000 feet of wetted channel length, and the loss between sites 3 and 5 averaged $2.1 \mathrm{ft}^{3} / \mathrm{s}$ per 1,000 feet of wetted channel length.

Dantz Run had an average loss of $1.1 \mathrm{ft}^{3} / \mathrm{s}$ per 1,000 feet of wetted channel length. On one occasion, a loss of $0.26 \mathrm{ft}^{3} / \mathrm{s}$ per 1,000 feet of wetted channel length was measured between sites 1 and 2 , and $2.4 \mathrm{ft}^{3} / \mathrm{s}$ per 1,000 feet of wetted channel length between sites 2 and 3. Canada Run had an average loss of $1.4 \mathrm{ft}^{3} / \mathrm{s}$ per 1,000 feet of wetted channel length. Average losses of 1.3 and $2.0 \mathrm{ft}^{3} / \mathrm{s}$ per 1,000 feet of wetted channel length were measured between sites 1 and 2 and between sites 2 and 3, respectively.

Heise Run was the only tributary stream that did not show consistent losses; it had an average infiltration gain of $0.07 \mathrm{ft}^{3} / \mathrm{s}$ per 1,000 feet of wetted channel length. The reach between sites 1 and $2 \mathrm{had}$ an average gain of $0.01 \mathrm{ft}^{3} / \mathrm{s}$ per 1,000 feet of wetted channel length, and the reach between sites 2 and 3 had an average gain of 0.10 $\mathrm{ft}^{3} / \mathrm{s}$ per 1,000 feet of wetted channel length.

\section{Water-Table Configuration Near the Streams}

The water table in Marsh Creek valley generally is below the surface of the tributary streams, and infiltration from flowing reaches of the tributary streams produces a localized mound in the water table. Water-level measurements show that the hydraulic gradient must be relatively steep near Asaph and Straight Runs, as suggested by figure 10 . A summary of waterlevel and completion data for selected wells near Asaph, Straight, Canada, Dantz, and Heise Runs is given in table 6. Average water levels differ from well to well and range from 1.7 to 21 feet below stream surface. The depth to water below stream surface generally increases with distance from the stream and the depth of well completion. The depth to water below stream surface generally increases away from the valley wall in the uppir reaches, is at a maximum in the middle reaches, and decreases toward Marsh Creek in the lower reaches. During high watertable conditions, water levels in the lower reaches may be slightly above the tributarystream surface.

Hydrologic sections show ground-water levels in relation to distance from the farthest downstream bedrock outcrop along Asaph and Straight Runs in figure 14 and in relation to distance from Asaph and Straight Runs in figure 15. Depth to water below stream surface generally is deeper along Straight Run than along Asaph Run because (1) Straight Run has a steeper stream gradient than Asaph Run, and the upper part of its alluvial fan therefore is higher than that of Asaph Run; (2) Straight Run has less flow than Asaph Run, and long reaches of the stream therefore are dry for longer periods; and (3) drawdown associated with pumping at the National Fisheries Research and Development Laboratory wellfield is concentrated near Straight Run.

Ground-water levels respond to the position of the point of stream dryness and the associated change in infiltration. Figure 16 shows the water levels in well 348 and the point of stream dryness along Asaph Run during the summer of 1985. When Asaph Run flows to Marsh Creek, such as from June to early July 1985, the water-level decline in well 348 results from the areal decrease in recharge and is gradual. As the point of 


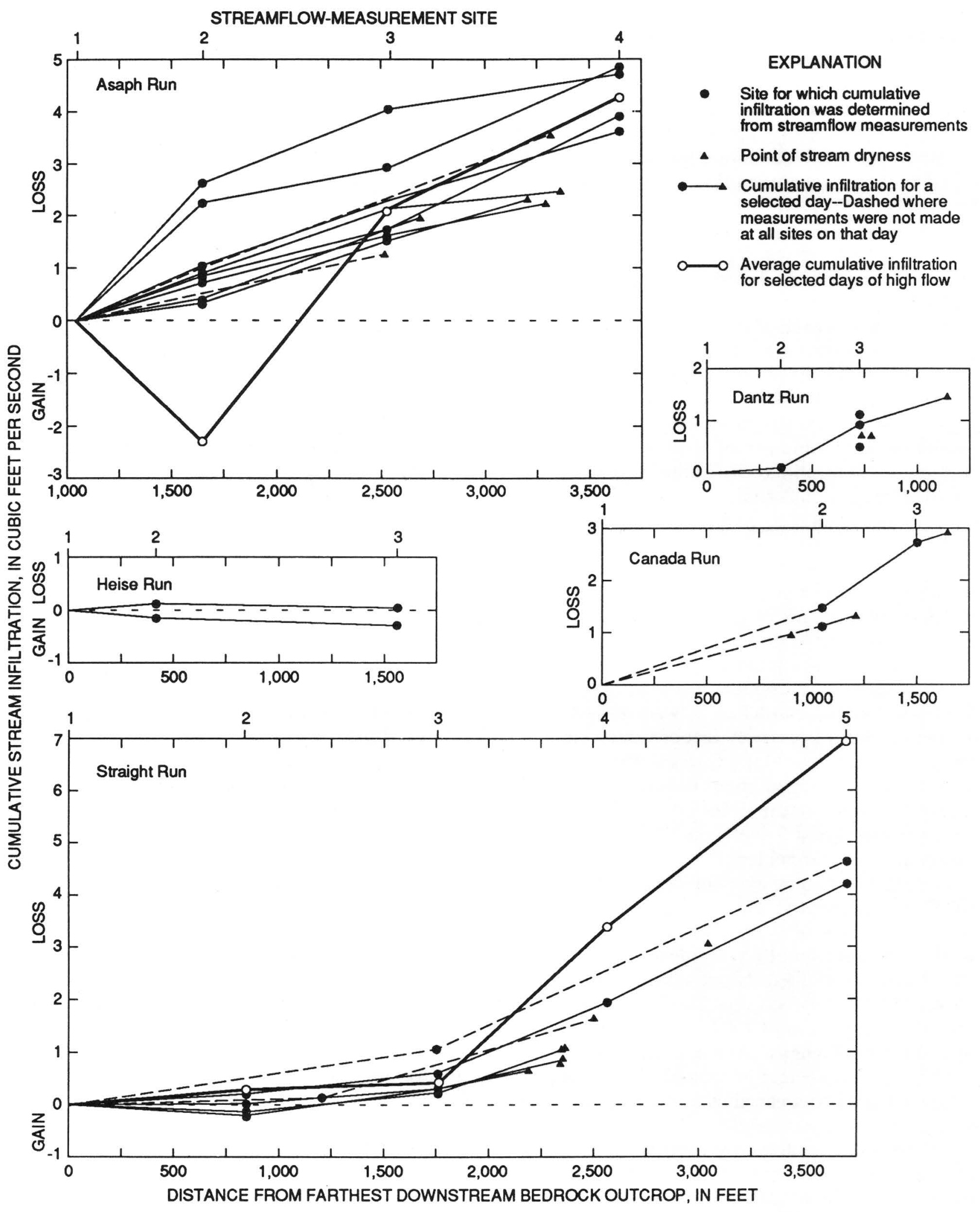

Figure 13.--Cumulative infiltration along the tributary streams.

(Locations are shown in fig. 6.) 
Table 5.-Infiltration rates along the tributary streams.

[Dash indicates no data. Locations shown in fig. 6.]

\begin{tabular}{|c|c|c|c|c|c|c|c|}
\hline \multirow[t]{2}{*}{ Stream } & \multirow[t]{2}{*}{ Date } & \multicolumn{6}{|c|}{ Infiltration rate, in cubic feet per second per 1,000 feet of channel length ${ }^{\mathbf{a}}$} \\
\hline & & \multicolumn{4}{|c|}{ REACH } & & \\
\hline \multirow[t]{14}{*}{ Asaph Run } & & $1-2$ & $2-3$ & 3-4 & $2-4$ & & \\
\hline & $06-28-84$ & 1.0 & 2.7 & $\overline{1.3}$ & 1.9 & & \\
\hline & $10-05-84$ & 1.4 & 3.0 & .59 & 1.0 & & \\
\hline & $12-18-84$ & -6.5 & 56 & 54 & 2.8 & & \\
\hline & 02-27-85 & -9.0 & 5.1 & 6.5 & 5.9 & & \\
\hline & $03-27-85$ & -.92 & 6.7 & -.64 & 2.7 & & \\
\hline & $04-24-85$ & 4.3 & 16 & .65 & 1.1 & & \\
\hline & $05-30-85$ & 3.8 & .47 & 1.9 & 1.3 & & \\
\hline & $07-23-85$ & 1.2 & 1.1 & .81 & .96 & & \\
\hline & 09-05-85 & .58 & 1.4 & 1.1 & 1.3 & & \\
\hline & 09-11-85 & .70 & 1.4 & 20 & 1.7 & & \\
\hline & $09-12-85$ & 1.7 & 1.4 & 1.2 & 1.3 & & \\
\hline & $10-23-85$ & 1.4 & 1.0 & 1.8 & 1.1 & & \\
\hline & Average & -0.03 & 2.6 & $\overline{1.5}$ & 1.9 & & \\
\hline \multirow[t]{11}{*}{ Straight Run } & & $1-2$ & $2-3$ & $1-3$ & $3-4$ & $4-5$ & $3-5$ \\
\hline & $06-28-84$ & - & - & .62 & - & - & 1.9 \\
\hline & $10-05-84$ & -.23 & .60 & .21 & .90 & - & .90 \\
\hline & $12-18-84$ & -.23 & 1.8 & .85 & 3.0 & 2.0 & 2.4 \\
\hline & $02-27-85$ & 1.1 & -2.7 & -.90 & 3.9 & 5.7 & 5.0 \\
\hline & $03-27-85$ & - & - & .79 & 4.3 & 1.8 & 2.8 \\
\hline & $04-24-85$ & .29 & .40 & .34 & 1.7 & 2.0 & 1.9 \\
\hline & $07-23-85$ & -.12 & .15 & .18 & 1.4 & - & 1.4 \\
\hline & 09-04-85 & -.14 & .47 & .18 & 1.3 & - & 1.3 \\
\hline & $10-23-85$ & .05 & .35 & .21 & .91 & - & .91 \\
\hline & Average & .10 & .15 & .28 & 2.2 & 2.9 & $\overline{2.1}$ \\
\hline \multirow[t]{7}{*}{ Dantz Run } & & $1-2$ & $2-3$ & $1-3$ & & & \\
\hline & $07-19-83$ & - & - & 0.91 & & & \\
\hline & $05-17-84$ & - & - & .72 & & & \\
\hline & $06-20-84$ & - & - & 1.6 & & & \\
\hline & $07-18-84$ & 0.26 & 2.4 & 1.4 & & & \\
\hline & $07-26-85$ & - & - & .74 & & & \\
\hline & Average & .26 & 2.4 & 1.1 & & & \\
\hline \multirow[t]{6}{*}{ Canada Run } & & $1-2$ & $2-3$ & $1-3$ & & & \\
\hline & $07-12-84$ & 1.4 & - & 1.4 & & & \\
\hline & $07-17-84$ & 1.4 & 2.8 & 1.8 & & & \\
\hline & $07-24-84$ & 1.1 & 1.1 & 1.1 & & & \\
\hline & $07-26-85$ & 1.1 & - & 1.1 & & & \\
\hline & Average & 1.3 & 2.0 & 1.4 & & & \\
\hline \multirow[t]{8}{*}{ Heise Run } & & $1-2$ & $2-3$ & $1-3$ & & & \\
\hline & $07-18-83$ & - & 0.03 & - & & & \\
\hline & $05-17-84$ & - & -.46 & - & & & \\
\hline & $06-20-84$ & - & .07 & - & & & \\
\hline & $07-19-84$ & - & -.03 & - & & & \\
\hline & $11-05-84$ & -0.23 & -.11 & -0.16 & & & \\
\hline & $07-26-85$ & .21 & -.09 & .02 & & & \\
\hline & Average & -.01 & -.10 & -.07 & & & \\
\hline
\end{tabular}

a Positive value indicates loss; negative value indicates gain. 

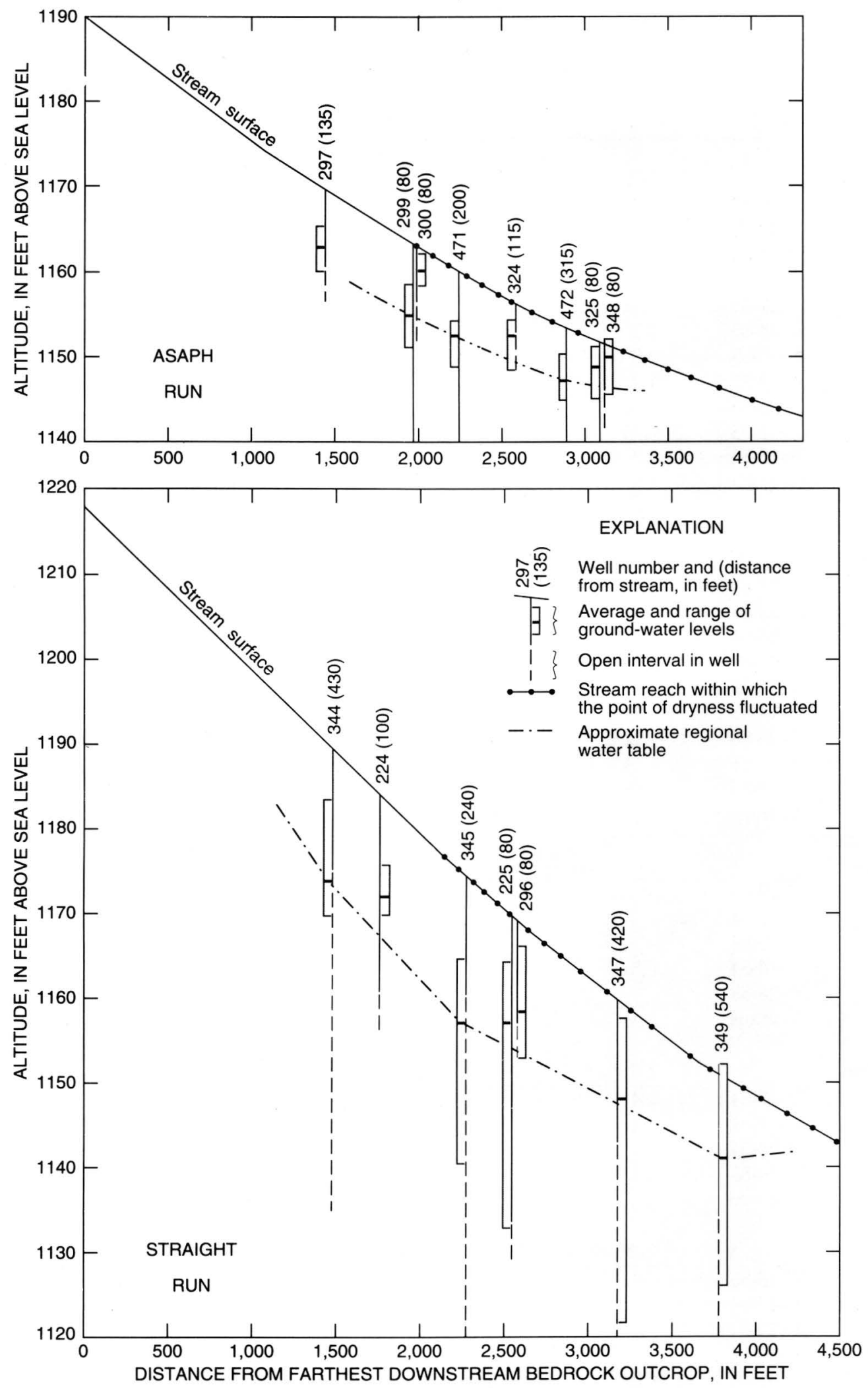

Figure 14.--Ground-water levels in relation to distance from farthest downstream bedrock outcrop along Asaph and Straight Runs. 

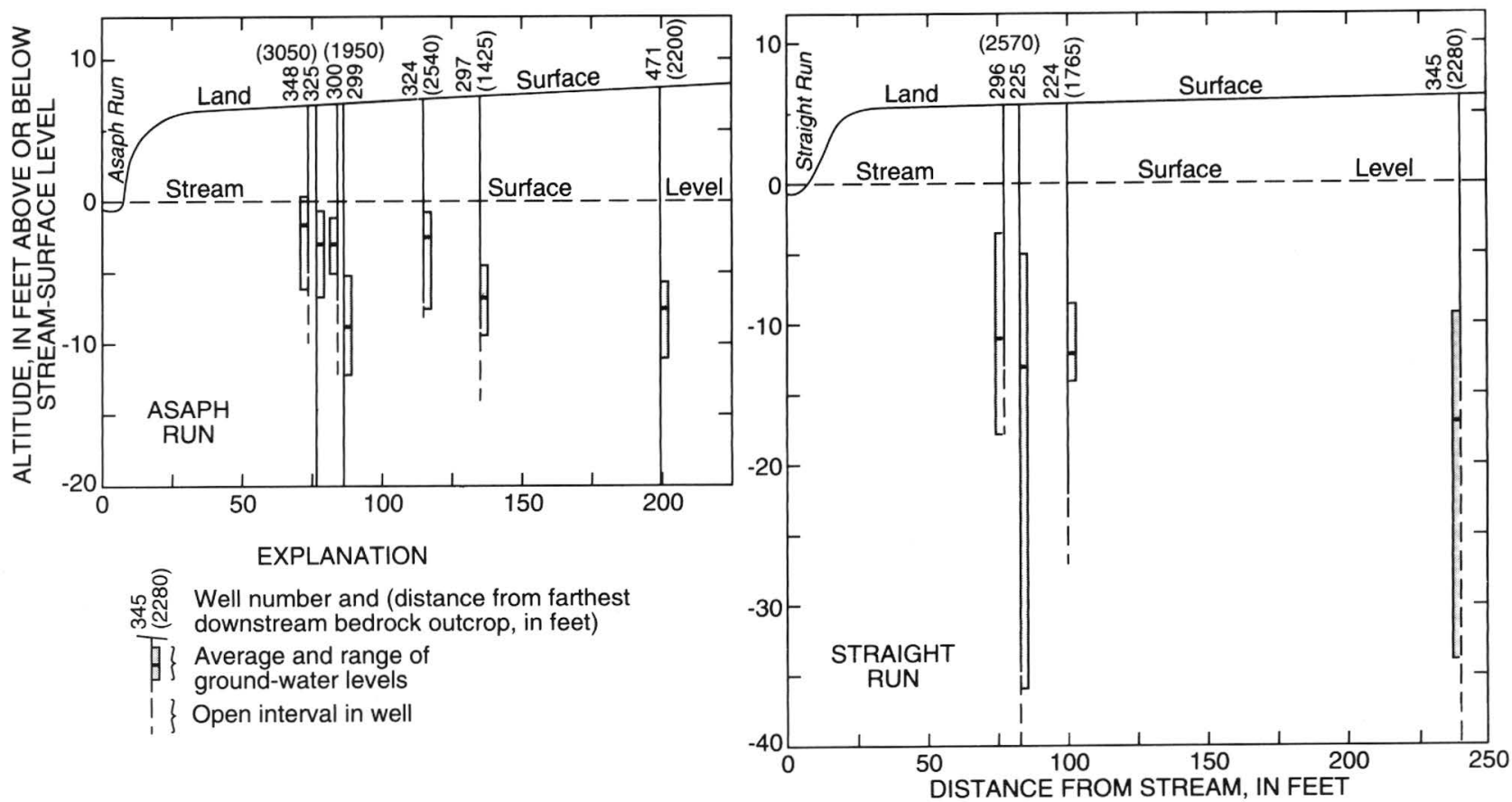

Figure 15.--Ground-water levels in relation to distance from Asaph and Straight Runs.

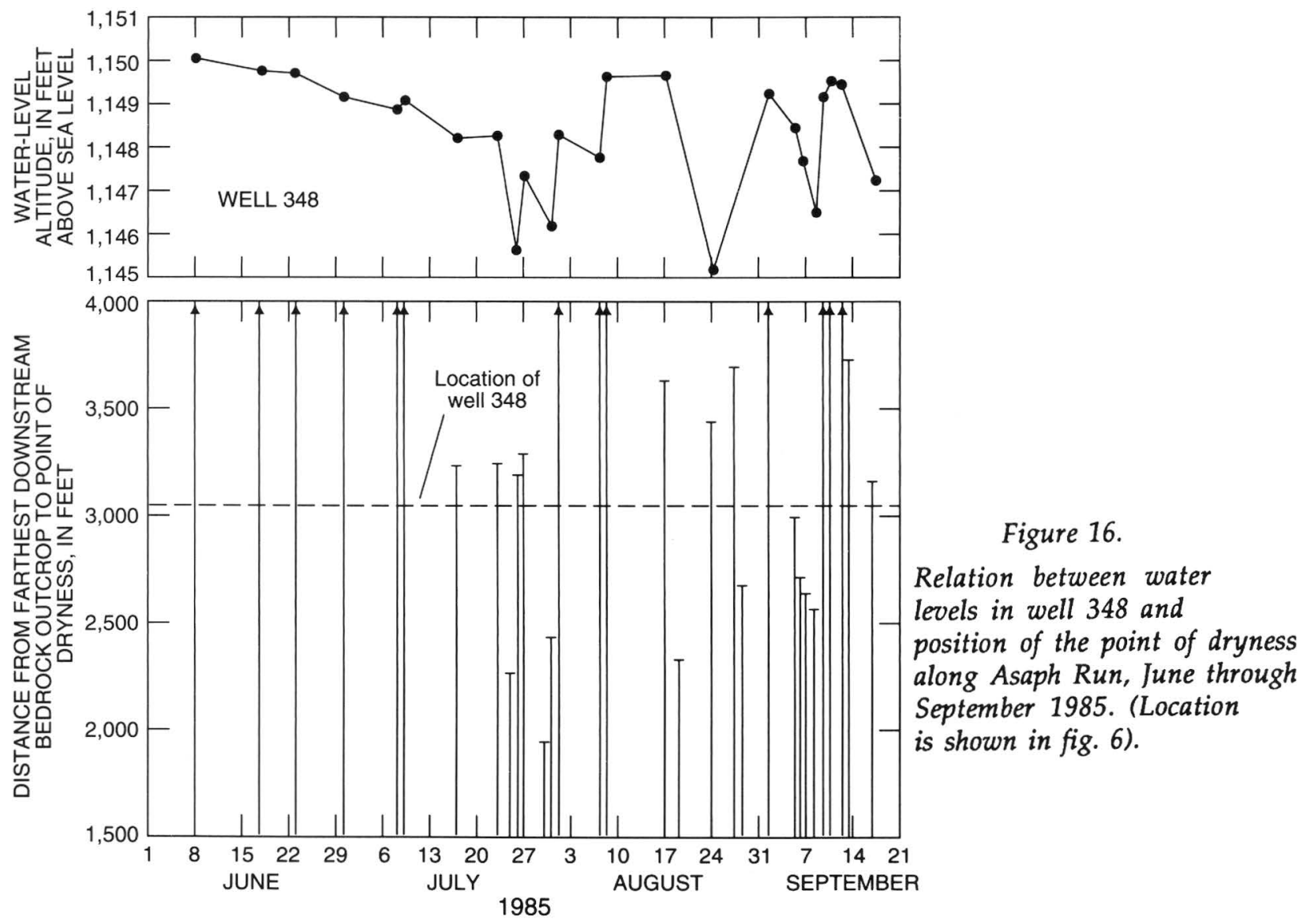


dryness in Asaph Run retreats past well 348 in late July, the water-level decline increases. In August and September, the water level rises in response to storms that cause Asaph Run to flow past the well, but quickly declines when the point of dryness begins to move upstream.

Hydrographs for selected wells along Asaph Run during water year 1985 are presented in figure 17. Water levels along reaches that have continuous flow, such as those observed in well
297, show minimal fluctuation except during the more extreme recharge events. Larger fluctuations are observed along reaches with discontinuous flow, particularly in the shallowest wells nearest the stream, such as wells 324 and 348 . Wells that are completed deeper and (or) farther from the stream, such as wells 325 and 472, generally show less fluctuation in response to the position of the point of dryness.

Table 6.--Summary of water levels and completion information in relation to stream surface for selected wells near the tributary streams.

[Dash indicates no data. Well locations shown in fig. 6.]

\begin{tabular}{|c|c|c|c|c|c|c|}
\hline \multirow[b]{2}{*}{ Well number } & \multirow{2}{*}{$\begin{array}{c}\text { Distance } \\
\text { from } \\
\text { valley wall, } \\
\text { in feet }\end{array}$} & \multirow{2}{*}{$\begin{array}{l}\text { Distance } \\
\text { from } \\
\text { stream, in } \\
\text { feet }\end{array}$} & \multirow{2}{*}{$\begin{array}{l}\text { Well depth, in } \\
\text { feet below } \\
\text { stream } \\
\text { surface }\end{array}$} & \multirow{2}{*}{$\begin{array}{l}\text { Casing depth, } \\
\text { in feet below } \\
\text { stream } \\
\text { surface }\end{array}$} & \multicolumn{2}{|c|}{$\begin{array}{c}\text { Depth to water level, in } \\
\text { feet below stream } \\
\text { surface }\end{array}$} \\
\hline & & & & & Average & Range \\
\hline \multicolumn{7}{|l|}{ Asaph Run } \\
\hline 297 & 1425 & 135 & 14 & 9 & 6.9 & $4.5-9.4$ \\
\hline 299 & 1950 & 80 & 40 & 35 & 8.8 & $5.1-12$ \\
\hline 300 & 1950 & 80 & 12 & 7 & 3.0 & $1.1-5.0$ \\
\hline 471 & 2200 & 200 & 39 & 34 & 7.4 & $5.8-11$ \\
\hline 324 & 2540 & 115 & 8 & 3 & 3.5 & $1.9-7.6$ \\
\hline 472 & 2840 & 315 & 76 & 76 & 6.1 & $3.2-9.1$ \\
\hline 325 & 3050 & & 47 & 37 & 3.0 & $0.6-6.6$ \\
\hline 348 & 3050 & 80 & 10 & 5 & 1.7 & $+0.4-6.1$ \\
\hline \multicolumn{7}{|l|}{ Straight Run } \\
\hline 344 & 1500 & 430 & 54 & 14 & 15 & $5.8-19$ \\
\hline 224 & 1765 & 100 & 27 & 22 & 12 & 8.3-14 \\
\hline 345 & 2280 & 240 & 54 & 14 & 17 & $9.4-34$ \\
\hline 346 & 2320 & 850 & 60 & 20 & 21 & $12-33$ \\
\hline 225 & 2570 & 80 & 40 & 35 & 13 & $5.0-36$ \\
\hline 296 & 2570 & 80 & 18 & 13 & 11 & $3.2->18$ \\
\hline 470 & 3090 & 940 & 74 & 67 & 17 & $8.7-35$ \\
\hline 476 & 3090 & 940 & 31 & 21 & 16 & $8.5->31$ \\
\hline 347 & 3125 & 420 & 57 & 17 & 12 & $2.6-38$ \\
\hline 349 & 3785 & 540 & 57 & 17 & 9.7 & $+1.3-25$ \\
\hline \multicolumn{7}{|l|}{ Canada . Run } \\
\hline 482 & 1300 & 300 & 111 & 70 & 12 & $9.3-15$ \\
\hline \multicolumn{7}{|l|}{ Dantz Run } \\
\hline 479 & 280 & 650 & 135 & - & 14 & $11-17$ \\
\hline 374 & 890 & 100 & 17 & 12 & 7.7 & - \\
\hline 480 & 890 & 1100 & - & - & 12 & $10-15$ \\
\hline \multicolumn{7}{|l|}{ Heise Run } \\
\hline 264 & - & 25 & 31 & 31 & 10 & $8.8-12$ \\
\hline 475 & - & 120 & 27 & 27 & 9.1 & $6.5-10$ \\
\hline
\end{tabular}

a Water levels measured between May 1984 and October 1985; + indicates above stream surface. 

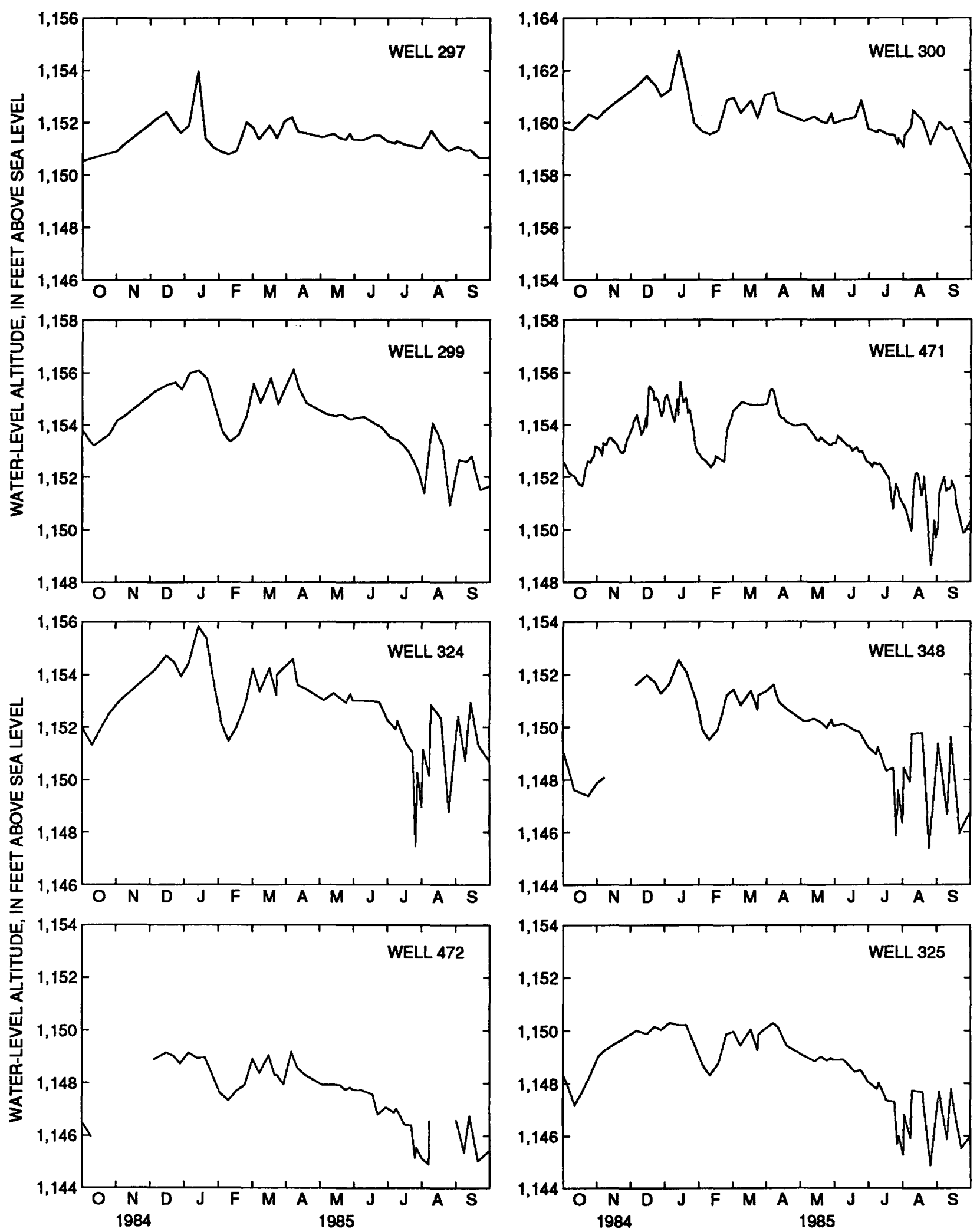

Figure 17.--Water levels in selected wells near Asaph Run, water year 1985.

(Well locations are shown in fig. 6.) 


\section{Factors That Affect Stream Infiltration}

Ground-water flow through porous media is governed by Darcy's Law, which is described by the following equation:

$$
Q=-K \frac{d h}{d l} A
$$

where

$$
\begin{array}{cl}
Q & =\text { flow through the porous medium, } \\
K & =\text { hydraulic conductivity, } \\
d h / d l & =\text { hydraulic gradient, and } \\
A & =\text { area perpendicular to flow. }
\end{array}
$$

Hydraulic conductivity is dependent on the characteristics of the porous medium as well as properties of the transmitted fluid. Hydraulic conductivity of an aquifer is described by the following equation:

$$
K=k \frac{\rho g}{\mu}
$$

where:

$$
\begin{array}{ll}
K & =\text { hydraulic conductivity, } \\
\boldsymbol{k} & =\text { intrinsic permeability of porous } \\
& \text { medium, } \\
\rho & =\text { density of water, } \\
\boldsymbol{g} & =\text { gravitational constant, and } \\
\mu & =\text { viscosity of water. }
\end{array}
$$

The density and viscosity of water are temperature dependent. The above equations, therefore, suggest that the following factors affect stream infiltration:

1) stream dimensions;

2) stream temperature;

3) hydraulic gradient near the streams; and

4) permeability of streambed and underlying aquifer.

\section{Stream Dimensions}

The wetted channel area of the stream, which is the length of the wetted channel multiplied by the wetted perimeter (approximated as the stream width plus two times the average depth, on the assumption that the stream has a roughly rectangular cross section), defines the area of infiltration. In the high-loss reaches of the streams, infiltration increases directly with wetted channel length, as shown in figure 16 and table 4. Infiltration per 1,000 feet of channel length between sites 2 and 4 on Asaph Run and sites 3 and 5 on Straight Run is plotted in relation to wetted perimeter in figure 18A. Wetted perimeter, which increases with increasing streamflow, ranged from 6.8 to 28.8 feet in Asaph Run and from 4.7 to 25.5 feet in Straight Run. The graph indicates that infiltration is relatively constant at smaller wetted perimeters and appears to generally increase at larger perimeters.

\section{Stream Temperature}

Changes in stream temperature theoretically may affect infiltration from the tributary streams by altering the viscosity of water. A decrease in temperature increases water viscosity and thereby causes a decrease in hydraulic conductivity. Infiltration per 15,000 square feet of wetted channel area between sites 2 and 4 on
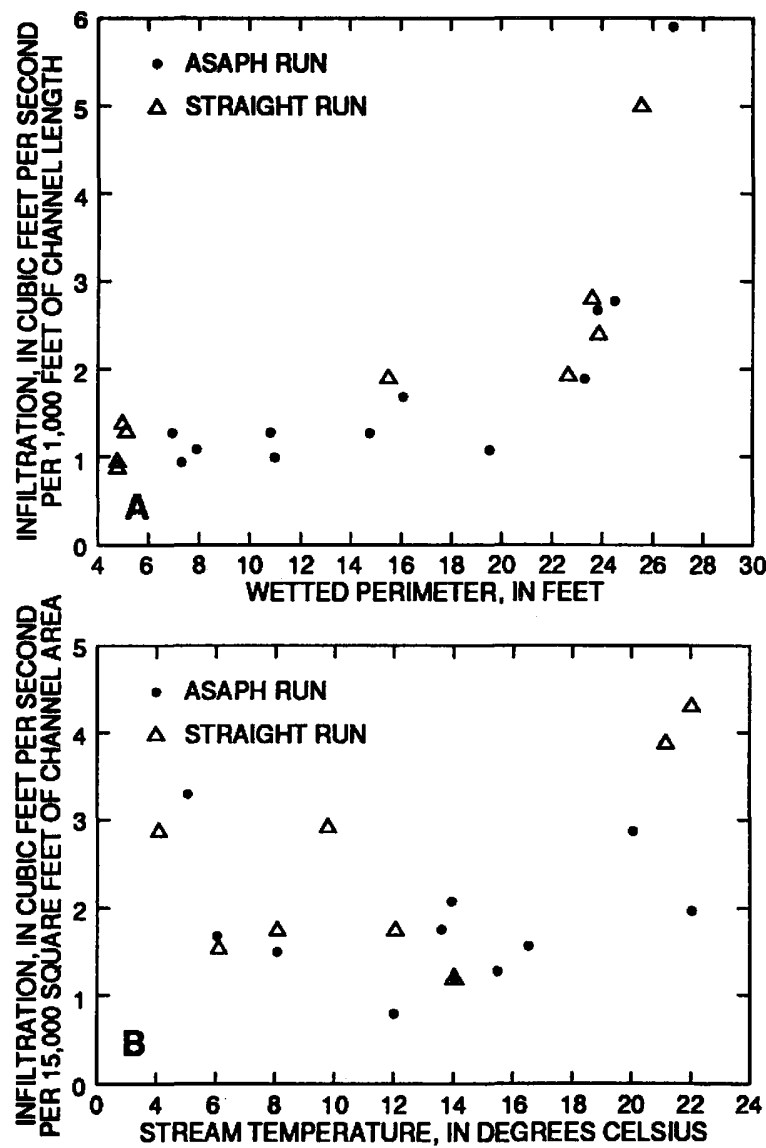

Figure 18.-Infiltration rate for Asaph and Straight Runs in relation to $(A)$ wetted perimeter, and (B) stream temperature. 
Asaph Run and sites 3 and 5 on Straight Run is plotted in relation to stream temperature in figure 18B. Stream temperature ranged from $4^{\circ} \mathrm{C}$ to $22^{\circ} \mathrm{C}$ (degrees Celsius). Within this temperature range, a $1^{\circ} \mathrm{C}$ decrease in temperature increases viscosity by about 2.2 percent (Bouwer, 1978). Infiltration does not appear to decrease with decreasing stream temperature, which suggests that infiltration may not be greatly affected by conditions in the immediate streambed.

\section{Hydraulic Gradient}

The difference between the water level in the stream and that in the shallow aquifer per unit distance from the stream is a measure of the hydraulic gradient of flow from infiltration. Infiltration per 15,000 square feet of wetted channel area between sites 2 and 4 on Asaph Run and sites 3 and 5 on Straight Run is plotted in relation to the hydraulic gradient near the

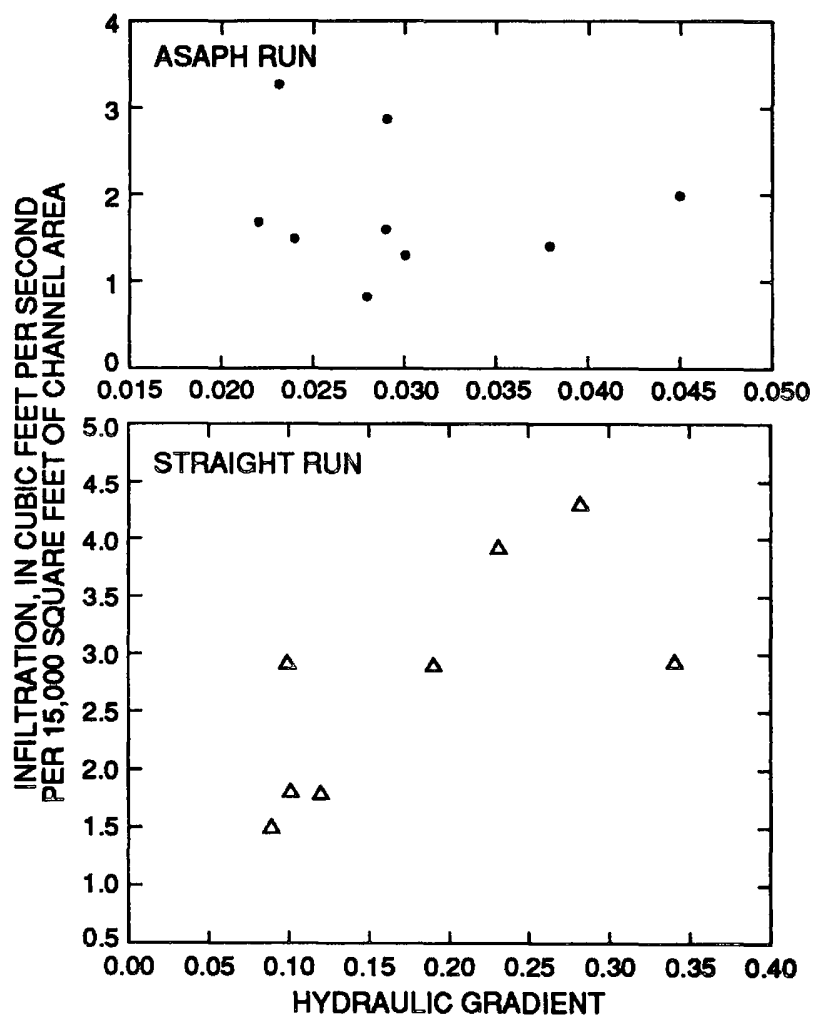

Figure 19.--Infiltration rate along Asaph and Straight Runs in relation to hydraulic gradient. middle of the respective reach in figure 19. The hydraulic gradients at Asaph Run were calculated from stream levels at site 3 and water levels in well 324, 115 feet from the stream, and at Straight Run from stream levels at site 4 and water levels in well 225, 80 feet from the stream. Hydraulic gradient at Asaph Run ranged from 0.022 to 0.045 . Hydraulic gradient at Straight Run, which is greater as a result of the steeper stream gradient and pumping effects from the National Fisheries Research and Development Laboratory wellfield, ranged from 0.088 to 0.34 . Hydraulic gradients generally were greatest in summer and early fall, when ground-water levels were low, and were least in early winter and early spring, when ground-water levels were high. Infiltration does not appear to increase with increasing hydraulic gradient over the narrow range of gradients at Asaph Run but does appear to increase with increasing hydraulic gradient over the wide range of gradients at Straight Run。

\section{Permeability}

Randall (1978) reports that "several papers dealing with infiltration from streams state or imply that the rate of infiltration is controlled by a thin streambed layer that is less permeable than the underlying sediment." He presents evidence that infiltration from tributary streams in the glaciated valleys of south-central New York may be controlled by the permeability of the deposits near the stream, rather than the streambed. Streambed permeability in the tributary streams studied in this investigation does not appear to be a major factor controlling infiltration. The permeability of the streambed and underlying deposits is a function of grain size, sorting, and compaction. The streambeds consist of loose, sandy gravel, and the alluvial-fan deposits near the streams consist of variably silty sand and gravel. Many silty beds were penetrated by shallow test holes near the streams. In general, the alluvial-fan deposits contain more silt and are less permeable than the streambed materials.

The streambeds of the tributary streams along reaches near highway and railroad bridges were excavated to depths of several feet during the spring of 1985, but the excavations did not produce any measurable changes in stream infiltration. Similarly, the lack of correlation between infiltration rate and stream temperature (fig. 
18B) suggests that the streambed permeability may not be a controlling factor.

Heise Run is the only stream investigated that does not lose water (fig. 13). The streambed of Heise Run does not appear to differ significantly from the others, but the nearby deposits appear to consist largely of fine-grained alluvium and swamp deposits rather than the coarser grained alluvial-fan deposits (pl. 1, section F-F'). The low permeability of these finegrained sediments near the stream may account for the lack of stream loss.

At high streamflows, infiltration occurs not only through the bottom of the streambed but also through the streambank. The interbedded nature of the alluvial-fan deposits indicates that horizontal permeability is greater than vertical permeability near the streams. Lateral flow through more permeable beds in the streambank may account for the apparent increase in loss with increasing wetting perimeter at larger perimeter (fig. 18A). At larger perimeters, as the stream approaches bankful, most of the increase in wetted perimeter is due to increases in stream depth, which would allow for greater loss by lateral flow through the streambank.

\section{Hydraulic Conductivity Near the Streams}

The hydraulic conductivity of the deposits near tributary streams can be estimated from stream-infiltration and ground-water-level data. Randall (1978) used a set of general solutions for infiltration from canals, developed by Bouwer (1965), to calculate hydraulic conductivity near selected tributary streams in south-central New York. Bouwer's solutions, presented in a series of graphs, were obtained by steady-state analysis for homogeneous and isotropic flow conditions with a resistance-network analog. Randall extrapolated these relations to the shallow streams he investigated. His estimates of hydraulic conductivity near the streams ranged from 13 to $130 \mathrm{ft} / \mathrm{d}$ and averaged $80 \mathrm{ft} / \mathrm{d}$. Assuming an anisotropy (ratio of horizontal to vertical hydraulic conductivity) of 10 to 1 , Randall estimated that horizontal hydraulic conductivity would be about 1.5 times the hydraulic conductivity calculated from the assumed isotropic conditions.

The solutions that were used to determine hydraulic conductivity near the streams in the present investigation were developed by $D$. J. Morrissey (U.S. Geological Survey, written commun., 1986). Expanding upon work by Bouwer (1965) as suggested by Randall (1978), Morrissey obtained solutions for infiltration from shallow streams by use of the finite-difference model program of McDonald and Harbaugh (1988). He developed a cross-sectional model that assumes homogeneous and isotropic flow conditions and constant heads in the stream nodes and in aquifer nodes at a distance of $\mathbf{2 0 0}$ feet from the stream. The model incorporated a 0.05 ratio of stream depth to stream width, which is generally representative of the streams in this investigation, and an impermeable boundary at the base of the aquifer. Solutions. were developed in which the ratio of boundary depth to stream width ranged from 1 to 5 . Bouwer (1965), in his analysis of losses from canals, concluded that any increase in depth to the impermeable boundary beyond five times the stream width had little effect on infiltration. In this investigation, bedrock is the only unit of low permeability that is continuous beneath the streams. In almost all reaches that were analyzed, the ratio of bedrock depth to stream width is greater than 5, although silty beds in the alluvial-fan and stratified-drift deposits form discontinuous layers of lower permeability at lesser depths. For the purpose of this analysis, the ratio of the depth of an impermeable boundary to stream width was assumed to be 5 .

Hydraulic conductivity of deposits near selected reaches of the streams was estimated by the following method. First, average values of stream width and depth, and of estimated depth to ground water below stream surface at 10 stream widths from the stream were calculated. The water levels in shallow wells were adjusted to 10 stream widths by assuming a logarithmic slope of the water table away from the stream. Then, the ratio of infiltration per unit area to hydraulic conductivity was estimated from figure 20 . Finally, hydraulic conductivity was calculated from that ratio and the known value of infiltration per unit area. Stream-infiltration variables and estimated hydraulic conductivity near selected reaches of the streams are presented in table 7. Estimated hydraulic-conductivity values range from 31 to $100 \mathrm{ft} / \mathrm{d}$ and average 61 $\mathrm{ft} / \mathrm{d}$. Significant parts of Dantz Run (reach 1 to 3 ) and Canada Run reaches ( 1 to 2 and 1 to 3 ) include zones of smaller loss near the valley wall and, as a result, estimated hydraulic conductivity values for these reaches are less than if only zones of greater loss had been included. 


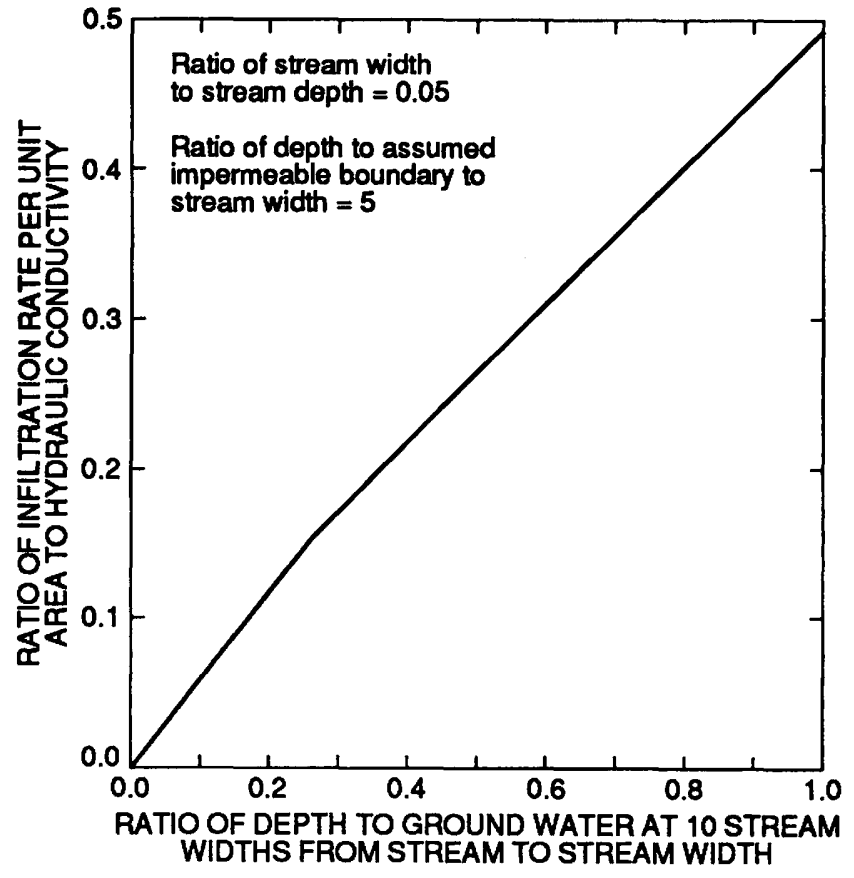

Figure 20.

Relation between ratio of infiltration to hydraulic conductivity and ratio of depth of ground water to stream width. (Modified from D.J. Morrissey, U.S. Geological Survey, written commun., 1986).

Table 7.--Stream-infiltration variables and estimated hydraulic conductivity near the tributary streams.

[Stream-infiltration variables measured between June 1984 and October 1985. Locations shown in fig. 6.]

\begin{tabular}{|c|c|c|c|c|c|c|}
\hline Stream & Reach & $\begin{array}{l}\text { Average } \\
\text { stream } \\
\text { width, in } \\
\text { feet }\end{array}$ & $\begin{array}{l}\text { Average } \\
\text { stream } \\
\text { depth, in } \\
\text { feet }\end{array}$ & $\begin{array}{l}\text { Average } \\
\text { infiltration rate } \\
\text { per } 1,000 \text { feet of } \\
\text { channel, in } \\
\text { square feet per } \\
\text { second }\end{array}$ & $\begin{array}{l}\text { Average estimated } \\
\text { depth to ground- } \\
\text { water level below } \\
\text { stream surface at a } \\
\text { distance of } 10 \text { stream } \\
\text { widths, in feet }\end{array}$ & $\begin{array}{l}\text { Average } \\
\text { hydraulic } \\
\text { conductivity } \\
\text { near the stream } \\
\text { reach, in feet } \\
\text { per day }\end{array}$ \\
\hline \multicolumn{7}{|l|}{ Asaph Run } \\
\hline & $2-3$ & 16 & 0.52 & 2.6 & 4.0 & 98 \\
\hline & $3-4$ & 13 & .46 & 1.5 & 3.7 & 61 \\
\hline & $2-4$ & 15 & .47 & 1.9 & 3.8 & 73 \\
\hline \multicolumn{7}{|l|}{ Straight Run } \\
\hline & $3-4$ & 13 & .28 & 2.2 & 8.4 & 44 \\
\hline & $4-5$ & 20 & .44 & 2.9 & 7.2 & 63 \\
\hline & $3-5$ & 14 & .29 & 2.1 & 8.6 & 41 \\
\hline \multicolumn{7}{|l|}{ Dantz Run } \\
\hline & $2-3$ & 5.0 & .34 & 2.4 & 4.1 & 100 \\
\hline & $1-3$ & 8.0 & .44 & 1.1 & 6.2 & 31 \\
\hline \multicolumn{7}{|l|}{ Canada Run } \\
\hline & $1-2$ & 7.4 & .35 & 1.3 & 7.0 & 33 \\
\hline & $2-3$ & 4.4 & .19 & 2.0 & 4.6 & 80 \\
\hline & $1-3$ & 6.5 & .34 & 1.4 & 4.8 & 50 \\
\hline
\end{tabular}


Recharge from Stream Infiltration

\section{Estimates of Recharge Rate}

Estimated rates of recharge from upland and valley sources to the stratified-drift aquifer along the investigated reach of Marsh Creek for water year 1985 are given in table 8. Recharge from Asaph and Straight Runs was estimated from a continuous record of streamflow near the valley wall, frequent observations of the point of stream dryness, and occasional synoptic streamflow measurements near the valley wall and at the farthest downstream site. When all flow infiltrated, which occured during about 30 percent of the water year in Asaph Run and 65 percent in Straight Run, recharge was equal to streamflow from the uplands as measured near the valley wall. When streamflow exceeded the amount that could infiltrate-about $4 \mathrm{ft}^{3} / \mathrm{s}$ in Asaph Run and 5 to $7 \mathrm{ft}^{3} / \mathrm{s}$ in Straight Runrecharge was assumed to equal infiltration estimated from five to eight sets of measurements at these higher flows. Measured losses for dates during which streamflow was $20 \mathrm{ft}^{3} / \mathrm{s}$ or greater (December 18, 1984, February 27, 1985, and March 27, 1985) were averaged for each stream. Infiltration for periods between measurements dates were estimated by linear interpolation. Figure 21 presents hydrographs of daily average streamflow from the upland drainage basins and infiltration in the Marsh Creek valley for Asaph and Straight Runs during water year 1985; monthly and annual averages of streamflow and infiltration are presented in table 9. Estimated recharge from infiltration for both streams was $3.7 \mathrm{ft}^{3} / \mathrm{s}$ during water year 1985 .

Continuous streamflow data were not collected on the other tributary streams, but daily average flows were estimated on the assumption that streamflow per unit area of upland was equal among all the upland drainage basins. The maximum infiltration rate along Dantz and Canada Runs was estimated from streamflow measurements to be about 1.5 and $3.0 \mathrm{ft}^{3} / \mathrm{s}$, respectively. Recharge was assumed to equal the maximum infiltration rate when estimated streamflow from the upland drainage basins exceeded this rate, and was assumed to equal streamflow from the upland drainage basins when streamflow was less than the maximum infiltration rate. Estimated recharge from infiltration of Dantz and Canada Runs during water year 1985 was 1.2 and $1.9 \mathrm{ft}^{3} / \mathrm{s}$, respectively. Streamflow measurements indicated that Heise Run did not contribute recharge. Three small unnamed tributaries-two near Heise Run and one between Heise Run and Dantz Run (fig. 2), also were assumed not to contribute recharge because of their proximity to Heise Run and the valley wall, respectively.

Recharge from infiltration of unchanneled runoff and ground-water inflow was estimated by applying the previously calculated rate of streamflow per unit area of upland drainage

Table 8.--Sources and estimated rates of recharge to the stratified-drift aquifer in Marsh Creek valley, water year 1985.

\begin{tabular}{lcc}
\hline Source of recharge & $\begin{array}{c}\text { Estimated rate of recharge, } \\
\text { in cubic feet per second }\end{array}$ & $\begin{array}{c}\text { Percentage } \\
\text { of total }\end{array}$ \\
\hline $\begin{array}{l}\text { Upland Sources } \\
\text { Tributary streams: }\end{array}$ & & \\
$\quad$ Asaph Run & 3.7 & 25 \\
$\quad$ Straight Run & 3.7 & 25 \\
$\quad$ Dantz Run & 1.2 & 8 \\
$\quad$ Canada Run & 1.9 & 13 \\
$\quad$ Subtotal & 10.5 & 71 \\
Ground-water inflow and $\quad$ unchanneled runoff & $\mathbf{2 . 7}$ & 18 \\
Subtotal & $\underline{13.2}$ & $\mathbf{8 9}$ \\
Precipitation on Valley & 1.7 & 11 \\
ALL SOURCES TOTAL & $\underline{14.9}$ & 100 \\
\hline
\end{tabular}


basins to the upland areas bordering the aquifer that are not drained by tributary streams. This estimate assumes that all precipitation not lost through evapotranspiration in these bordering areas either infiltrates and flows laterally into the stratified-drift aquifer or flows overland and infiltrates at the valley wall. Estimated recharge from unchanneled runoff and groundwater inflow from the bordering upland areas during water year 1985 was $2.7 \mathrm{ft}^{3} / \mathrm{s}$.

Recharge from infiltration of precipitation on the valley was estimated by applying the rate of streamflow per unit area of upland to the area of the valley. This estimate assumes that

Table 9.--Monthly and annual averages of streamflow from the upland drainage basins and infiltration in Marsh Creek valley for Asaph and Straight Runs, water year 1985.

[Flow and infiltration rates are in cubic feet per second.]

\begin{tabular}{|c|c|c|c|c|}
\hline & \multicolumn{2}{|c|}{$\begin{array}{l}\text { Streamflow near } \\
\text { valley wall }\end{array}$} & \multicolumn{2}{|c|}{ Tributary-stream infiltration } \\
\hline & Asaph Run & Straight Run & Asaph Run & Straight Run \\
\hline October 1984 & 3.6 & 1.1 & 2.8 & 1.1 \\
\hline November & 13 & 4.5 & 42 & 3.4 \\
\hline December & 39 & 19 & 4.2 & 7.0 \\
\hline January 1985 & 13 & 7.7 & 4.2 & 4.8 \\
\hline February & 27 & 10 & 4.0 & 3.6 \\
\hline March & 39 & 18 & 4.2 & 7.0 \\
\hline April & 29 & 11 & 3.5 & 5.1 \\
\hline May & 6.9 & 3.4 & 4.6 & 3.1 \\
\hline June & 9.9 & 4.0 & 4.7 & 3.8 \\
\hline July & 3.6 & 2.0 & 2.9 & 2.0 \\
\hline August & 3.8 & 2.0 & 2.4 & 1.7 \\
\hline September & $\underline{2.9}$ & 1.4 & 2.4 & 1.4 \\
\hline Water year 1985 & 16 & $\overline{7.0}$ & $\overline{3.7}$ & $\overline{3.7}$ \\
\hline
\end{tabular}
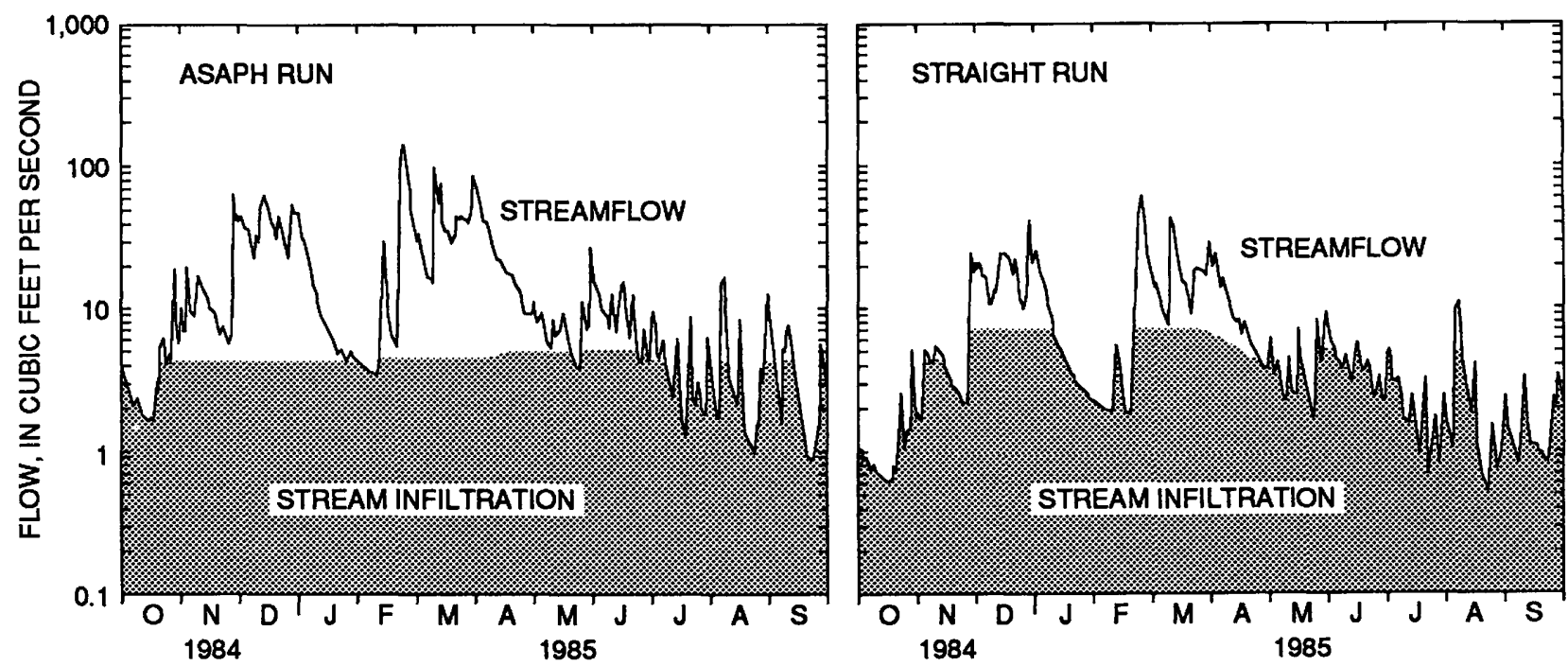

Figure 21.--Streamflow from the upland drainage basins and infiltration in Marsh Creek valley for Asaph and Straight Runs, water year 1985. 
evapotranspiration per unit area is the same in the upland and the valley and that all precipitation on the valley that is not lost through evapotranspiration infiltrates and recharges the aquifer. In alluvial fans and areas near the valley walls that are underlain by icecontact deposits, the greater depths to the water table may result in less evapotranspiration than in the uplands, whereas the extensive swampy areas in the valley would produce more evapotranspiration than the uplands. Estimated recharge from precipitation on the valley during water year 1985 was $1.7 \mathrm{ft}^{3} / \mathrm{s}$.

Tributary-stream infiltration accounted for more than 70 percent of the estimated recharge to stratified-drift aquifer along the investigated reach of Marsh Creek during water year 1985. Ground-water inflow and unchanneled runoff accounted for about 18 percent of the estimated recharge, and the precipitation on the valley accounted for about 11 percent.

\section{Effects of Recharge on Drawdown near the National Fisheries Research and Development Laboratory Wellfield}

The temporal variation in recharge from tributary-stream infiltration significantly affects the drawdown in the stratified-drift aquifer caused by pumping at the National Fisheries Research and Development Laboratory wellfield. The effect of tributary-stream infiltration on drawdown was demonstrated by a series of aquifer tests. The first test was completed during
November 7-10, 1977, by a private drilling contractor; the other two were completed during September 5-8 and 16-20, 1985 by the U.S. Geological Survey and U.S. Fish and Wildlife Service. In well 1 , which is in a geohydrologic setting similar to Asaph Run, 8 miles to the west, the average water levels during November 1977 and September 1985 were 4 feet higher and 3 feet lower, respectively, than the annual average water level over the previous 50 years of record.

During the aquifer test in November 1977, the three production wells and the domestic well at the National Fisheries Research and Development Laboratory (fig. 22) were pumped at a combined rate of $7.1 \mathrm{ft}^{3} / \mathrm{s}$ for 60 hours (table 10). Comparison of flow in Straight Run with that in Corey Creek, which is 14 miles to the east and has been gaged since 1954, indicates that flow in Straight Run must have exceeded $50 \mathrm{ft}^{3} / \mathrm{s}$ during the 1977 test (R. A. Hainly, U.S. Geological Survey, written commun., 1986). Therefore, Straight Run must have flowed all the way to Marsh Creek during the test, and stream infiltration is estimated to have been at the maximum rate measured in water year 1985, about $6 \mathrm{ft}^{3} / \mathrm{s}$. Water levels in the observation wells stabilized at altitudes ranging from about 1,150 to 1,165 feet above sea level within 48 hours of the start of pumping (fig. 23).

Two days before the start of the September 58,1985 test, the combined pumping rate from the three production wells was reduced from 3.4 to 2.4 $\mathrm{ft}^{3} / \mathrm{s}$ (fig. 8). Water levels in the wellfield area appeared to be relatively stable before the

Table 10.--Summary of selected aquifer tests at the National Fisheries Research and Development Laboratory wellfield.

[Rates are in cubic feet per second. Dash indicates zero. Well locations shown in fig. 22.]

\begin{tabular}{|c|c|c|c|c|c|c|c|c|c|c|}
\hline & & \multirow{3}{*}{$\begin{array}{l}\text { Length } \\
\text { of test, } \\
\text { in hours }\end{array}$} & \multicolumn{4}{|c|}{ Pumping rate } & \multirow{3}{*}{\multicolumn{2}{|c|}{$\begin{array}{l}\text { Augmentation } \\
\text { rate from } \\
\text { Straight Run }\end{array}$}} & \multirow{2}{*}{\multicolumn{2}{|c|}{$\begin{array}{c}\text { Infiltration rate } \\
\text { from Straight } \\
\text { Run }\end{array}$}} \\
\hline \multicolumn{2}{|c|}{ Period of test } & & Well & Well & Well & Well & & & & \\
\hline Start & End & & 269 & 271 & 272 & 270 & & & Start & End \\
\hline $11-07-77$ & $11-10-77$ & 60 & 2.2 & 2.2 & 2.2 & 0.45 & 7.1 & - & $6^{a}$ & $6^{a}$ \\
\hline $09-8-85$ & 09-08-85 & 68 & 1.8 & 2.2 & $1.8 / 0.7^{b}$ & - & $5.8 / 4.7^{\mathrm{b}}$ & - & 1.0 & .82 \\
\hline $09-16-85$ & 09-20-85 & 92 & 1.5 & 1.9 & 0.6 & - & 4.0 & 1.6 & 2.7 & 2.5 \\
\hline
\end{tabular}

a Estimated (streamflow in Straight Run was greater than $50 \mathrm{ft}^{3} / \mathrm{s}$ ).

b Pumping rate in well 272 was reduced between 24 and 30 hours. 
aquifer test started. The combined pumping rate from the three wells for the first 24 hours of the test was $5.8 \mathrm{ft}^{3} / \mathrm{s}$ (table 10 and fig. 8). The pumping rate in well 272 was reduced twice between 24 and 30 hours into the test because the water level was rapidly approaching the top of the well screen and pump intake at an altitude of 1,092 feet above sea level; the combined rate for the remaining 38 hours of the test was $4.7 \mathrm{ft}^{3} / \mathrm{s}$. Streamflow from the upland drainage basin of Straight Run at the start of the test was $1.0 \mathrm{ft}^{3} / \mathrm{s}$, and the point of dryness was more than 250 feet upstream of the closest production well. Water levels measured in observation wells at the start of the test were 15 to 20 feet lower than those at the start of the November 1977 test (fig. 23A) as a result of previous pumping from the wellfield and lower recharge prior to the test. After 68 hours, water levels in the observation wells failed to stabilize, and at the end of the test, the water level in well 347, near the center of the wellfield, had declined to an altitude of 1,122 feet above sea level and was still declining at a rate of 0.11 feet per hour.

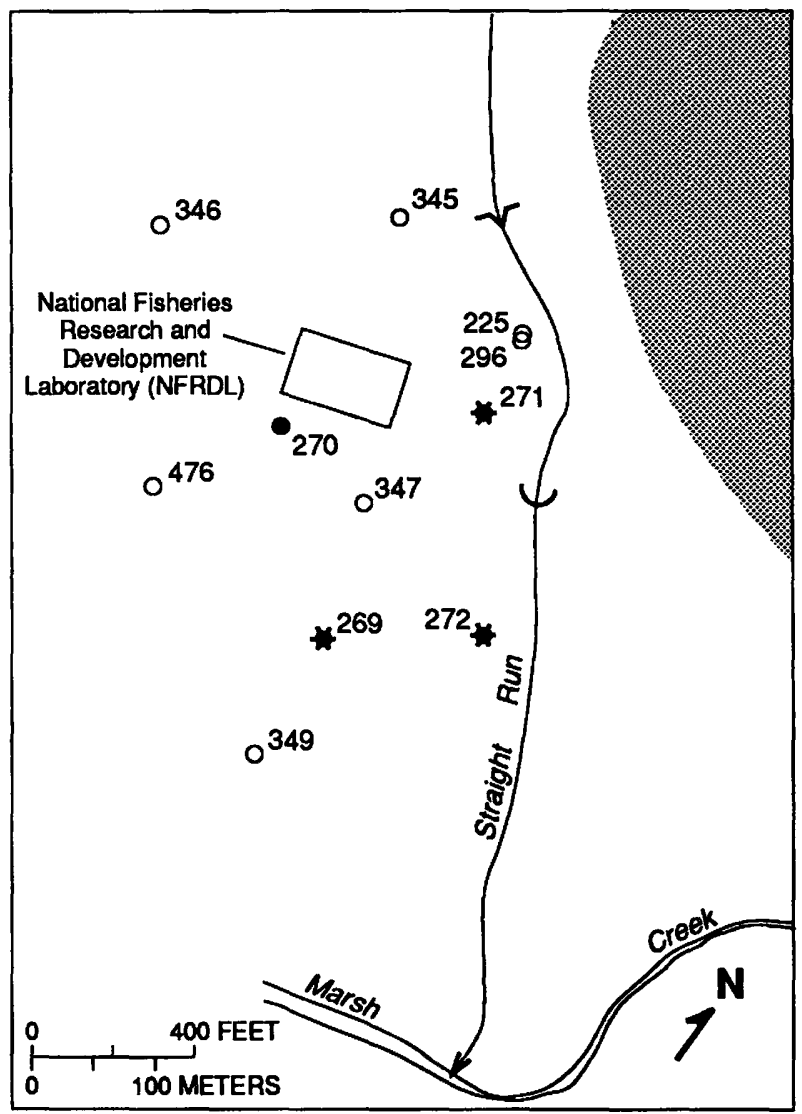

The three production wells were continuously pumped at a combined rate of $4.7 \mathrm{ft}^{3} / \mathrm{s}$ from the end of September 5-8, 1985 test to the beginning of the September 16-20 test. Recharge from precipitation (fig. 7) starting at the end of the September 5-8 test caused water levels to rise in the observation wells in the wellfield area, and the water levels continue to rise until September 11 , after which they began to decline. Water levels before the start of the September 16-20 test were slightly below those at the end of the September 5-8 test and were still declining. For example, the water level in well 347 , near the center of the wellfield, was at an altitude of 1,119 feet and was declining at a rate of 0.07 feet per hour.

The three production wells were pumped at a combined rate of $4.0 \mathrm{ft}^{3} / \mathrm{s}$ for 92 hours during the September 16-20 test (table 10). Streamflow from the upland drainage basin of Straight Run at the start of the test was $1.1 \mathrm{ft}^{3} / \mathrm{s}$. Instead of discharging all the pumped water to Marsh Creek, $1.6 \mathrm{ft}^{3} / \mathrm{s}$ was used to augment streamflow in Straight Run 1,500 feet upstream of the wellfield.

EXPLANATION

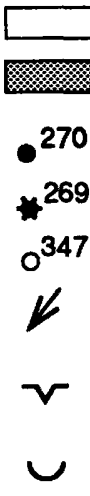
VALLEY

UPLANDS

NFRDL DOMESTIC WELL

NFRDL PRODUCTION WELL

OBSERVATION WELL

STREAMFLOW TO MARSH CREEKNovember 7-10, 1977

POINT OF STREAM DRYNESSSeptember 5-8, 1985

POINT OF STREAM DRYNESSSeptember 16-20, 1985, during streamflow augmentation

Figure 22.

Location of pumped and selected observation wells and points of stream dryness in Straight Run from aquifer tests of November 7-10, 1977 and September 5-8 and 16-20, 1985, at the National Fisheries Research and Development Laboratory wellfield. 

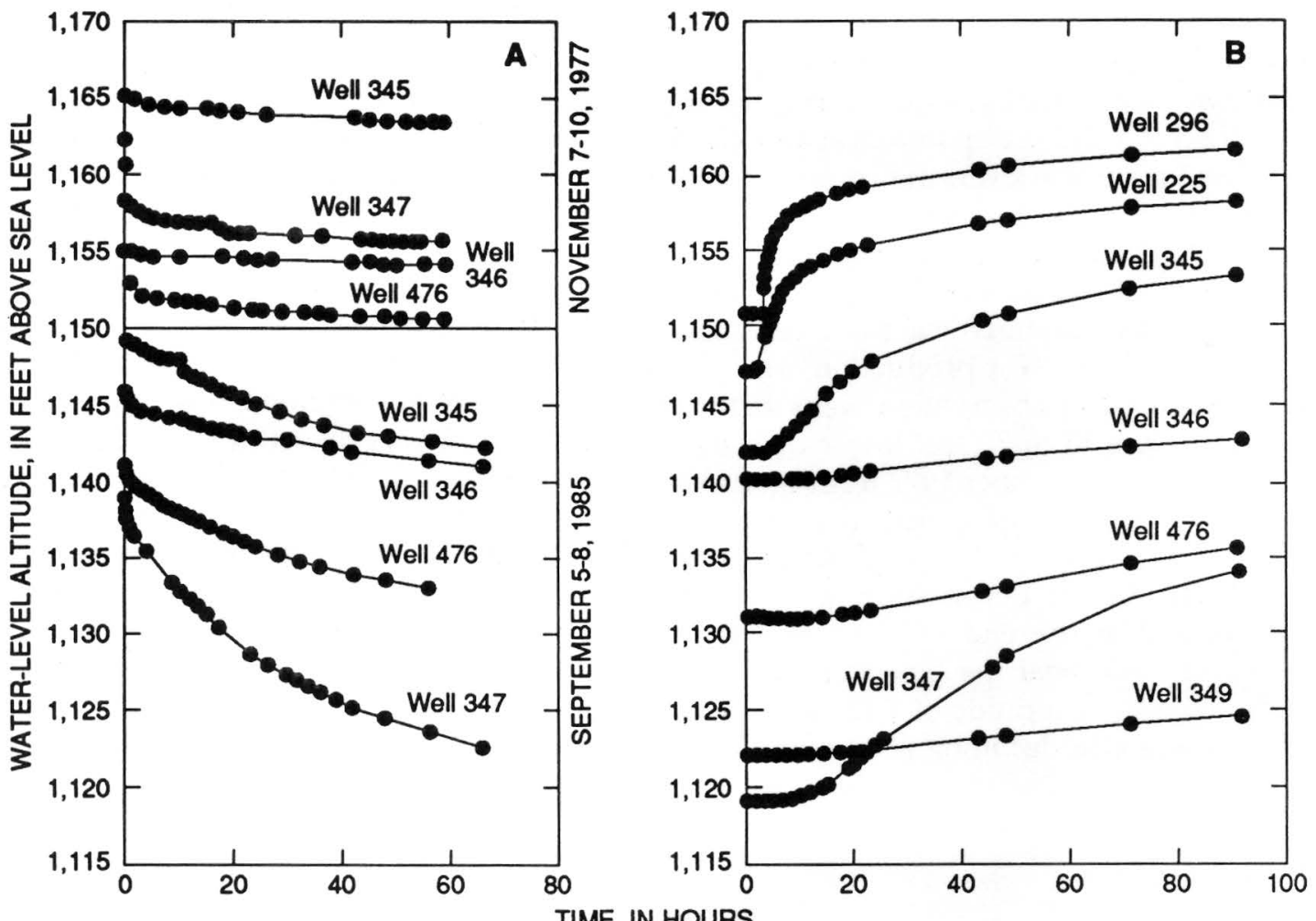

Figure 23.--Water levels in selected observation wells during aquifer tests at the National Fisheries Research and Development Laboratory wellfield:

A. November 7-10, 1977 and September 5-8, 1985. B. September 16-20, 1985.

With augmentation, flow in Straight Run passed the closest production well and approached the center of the wellfield. During the first 3 hours of the test, before the start of recovery in response to streamflow augmentation, water levels in the wellfield area rose slightly in response to the decrease in pumpage from 4.7 to $4.0 \mathrm{ft}^{3} / \mathrm{s}$. For example, well 347 showed a recovery of 0.2 feet, 50 percent of which occurred in the first 0.5 hours. Recovery resulting from the decreased pumpage presumably continued after 3 hours but would be insignificant compared with that which resulted from streamflow augmentation.

The response time of water-level recovery in the observation wells after streamflow augmentation increased with increasing distance from the flowing stream. Water levels in wells 225 and 296 (shallow wells 80 feet from Straight Run) showed the most rapid recovery during the first part of the test and had risen more than 10 feet after 92 hours (fig. 23B). Water levels in wells 346,349 , and 476 , which are 850 to 950 feet from the flowing stream, recovered more slowly, rising 2 to 4 feet by the end of the test. The water level in well 347, near the center of the wellfield, had the greatest recovery, rising about 15 feet and reaching an altitude of 1,135 feet above sea level by the end of the test. 


\section{SUMMARY}

Infiltration from five tributary streams along a 3.6-mile reach of Marsh Creek valley in northcentral Pennsylvania was investigated during 1983-85 as part of the Northeast Glacial Regional Aquifer-Systems Analysis Program of the U.S. Geological Survey. Pumping from the wellfield of the National Fisheries Research and Development Laboratory near Straight Run within Marsh Creek valley, the only major ground-water withdrawal in the study area, increased from 0.5 to $3.2 \mathrm{ft}^{3} / \mathrm{s}$ during water years 1984 and 1985.

Marsh Creek valley is underlain by up to 100 feet of stratified drift that overlies Devonian bedrock and is overlain by up to 30 feet of alluvial-fan deposits near the tributary streams. The tributary streams drain upland basins that are mantled with till and underlain by bedrock of Devonian to Pennsylvania age.

The stratified drift and overlying postglacial deposits form a complex system of aquifer and confining units. Estimates of the hydraulic conductivity of the stratified-drift aquifer near Straight and Asaph Runs range from 38 to $330 \mathrm{ft} / \mathrm{d}$ and average $200 \mathrm{ft} / \mathrm{d}$. Water from the tributary streams draining the uplands and from the stratified-drift aquifer near Asaph and Straight Runs contains less than $100 \mathrm{mg} / \mathrm{L}$ of total dissolved solids; the major cation is calcium, and the major anion is bicarbonate. Water from restricted-flow zones in the bedrock underlying Marsh Creek valley is characterized as sodiumchloride type and has a total dissolved solids concentration of more than $500 \mathrm{mg} / \mathrm{L}$.

Asaph, Straight, Dantz, and Canada Runs lose large amounts of water to the aquifer in Marsh Creek valley; infiltration from these streams along reaches away from the valley wall averaged about $2 \mathrm{ft}^{3} / \mathrm{s}$ per 1,000 feet of wetted channel length. Heise Run had minimal losses or small gains. Infiltration produces localized water-table mounds near the tributary streams. The depth to water in wells near the streams generally increases with distance from the stream and depth of well completion. The point of maximum depth to water in wells near the streams generally is midway between the Marsh Creek valley wall and the stream mouth.

The permeability of the streambeds, which consist of loose, sandy gravel, does not appear to control infiltration from the tributaries, but silty deposits of lower permeability near the streams may significantly affect infiltration. Estimates of hydraulic conductivity of the deposits near Asaph, Straight, Dantz, and Canada Runs range from 31 to $100 \mathrm{ft} / \mathrm{d}$ and average $61 \mathrm{ft} / \mathrm{d}$. The low permeability of the sediments near Heise Run, which probably consist largely of fine-grained alluvium and swamp deposits rather than the coarser grained alluvial-fan deposits, may account for the lack of infiltration along this stream.

Rates of recharge to the stratified-drift aquifer along the 3.6-mile reach of Marsh Creek valley were estimated for water year 1985, a period in which annual precipitation was below average. Sources and rates, in $\mathrm{ft}^{3} / \mathrm{s}$, of recharge are as follows:

(1) direct infiltration of precipitation in the valley, 1.7;

(2) unchanneled runoff and ground-water inflow from the uplands, 2.7; and

(3) tributary-stream infiltration: Asaph Run, 3.7, Straight Run, 3.7, Dantz Run, 1.2, and Canada Run, 1.9.

Tributary-stream infiltration accounted for more than $\mathbf{7 0}$ percent of the estimated recharge. Infiltration induced from Marsh Creek and swamps by pumping at the National Fisheries Research and Development Laboratory wellfield is probably minimal because these areas are underlain by $\mathbf{1 0}$ to 15 feet of fine-grained alluvium and swamp deposits.

Temporal variation in tributary-stream infiltration greatly affects drawdowns associated with pumping at the National Fisheries Research and Development Laboratory wellfield. Water levels in observation wells stabilized within 48 hours of pumping at $7.1 \mathrm{ft}^{3} / \mathrm{s}$ when Straight Run flowed all the way to Marsh Creek and infiltration from the stream was at the maximum rate of about $6 \mathrm{ft}^{3} / \mathrm{s}$.

In contrast, water levels failed to stabilize even after 68 hours of pumping at 4.7 to $5.8 \mathrm{ft}^{3} / \mathrm{s}$ when upland streamflow in Straight Run was less than $1 \mathrm{ft}^{3} / \mathrm{s}$ and the stream went dry about 250 feet upstream of the closest production well. Water levels recovered 2 to 15 feet near the wellfield after the natural streamflow of about $1 \mathrm{ft}^{3} / \mathrm{s}$ was augmented by $1.6 \mathrm{ft}^{3} / \mathrm{s}$ for 92 hours, which caused Straight Run to flow past the closest production well and approach the center of the wellfield. 


\section{REFERENCES CITED}

Babcock, H. M. and Cushing, E. M., 1942, Recharge to groundwater from floods in a typical desert wash, Penal County, Arizona: Transactions American Geophysical Union, v. 23, p. 49-55.

Becher, A. E. and Root, S. I., 1981, Groundwater resources and geology of Cumberland valley, Cumberland County, Pennsylvania: Pennsylvania Geological Survey Water Resources Report 50, 95 p.

Berg, T. M. and Dodge, C. M. 1981, Atlas of preliminary geologic maps of Pennsylvania: Pennsylvania Geological Survey Map 61, 636 p.

Bouwer, Herman, 1965, Theoretical aspect of seepage from open channels: American Society of Civil Engineers Proceedings, Journal Hydraulics Division, v. 91, no. HY3, p. 37-59.

1978, Groundwater hydrology: New York, McGrawHill, 480 p.

Bradbury, K. R. and Rothschild, E. R., 1985, A computerized technique for estimating the hydraulic conductivity of aquifers from specific capacity data: Groundwater, v. 23, no. 2, p. 240-245.

Brons, F. and Marting, V. E., 1961, The effect of restricted fluid entry on well productivity: Journal of Petroleum Technology, v. 13, no. 2, p. 172-174.

Haeni, F. P., 1986, Application of seismic-refraction methods in ground-water modeling studies in New England: Geophysics, v. 51, no. 2, p. 236-249.

1988, Application of seismic-refraction tech-niques to hydrologic studies: U.S. Geological Survey Techniques of Water-Resources Investigations, book 2 , chap. D2, 86 p.

Kennedy, E. J., 1984, Discharge ratings at gaging stations: U.S. Geological Survey Techniques of Water-Resources Investigations, book 3, chap. A10, 59 p.

Lyford, F. P., 1986, Northeast glacial regional aquifersystem study, in Sun, R.J., ed., Regional aquifer- system analysis program of the U.S. Geological Survey, summary of projects, 1978-1984: U.S. Geological Survey Circular 1002, 264 p.

McDonald, M. G. and Harbaugh, A. W., 1988, A modular three-dimensional finite-difference ground-water flow model: U.S. Geological Survey Techniques of Water-Resources Investigations, book 6, chap. A1, 586 p.

National Oceanic and Atmospheric Administration, 1985, Climatological data for Pennsylvania, v. 90, nos. 1 through 12.

Randall, A. D., 1978, Infiltration from tributary streams in the Susquehanna River basin, New York: U.S. Geological Survey Journal of Research, v. 6, no. 3, p. 285-297.

Scott, J. H., Tibbitts, and B. L., Burdick, R. G., 1972, Computer analysis of seismic refraction data: U.S. Bureau of Mines Report of Investigations 7595, $95 \mathrm{p}$.

Taylor, L. E., Werkheiser, W. H., and Kriz, M. L., 1983, Groundwater resources of the West Branch Susquehanna River Basin, Pennsylvania: Pennsylvania Geological Survey Water Resources Report 56, 143 p.

Theis, C. V., Brown, R. H., and Meyer, R. R., 1963, Estimating the transmissivity of aquifers from the specific capacity of wells in Bentall, Ray, ed. Methods of determining permeability, transmissivity, and drawdown: U.S. Geological Survey Water-Supply Paper 1536-I, p. 331-341.

Zhody, A. A. R., 1973, A computer program for the automatic interpretation of Schlumberger sounding curves over horizontally stratified media: U.S. Geological Survey Report USGS-GD-74-017, 25 p.

Zhody, A. A. R., Eaton, G. P., and Mahby, D. R., 1974, Applications of surface geophysics to ground water investigations: U.S. Geological Survey Techniques of Water Resources Investigations, book 2, chap. D1, $116 \mathrm{p}$. 


\section{APPENDIXES}

1. Completion information for selected wells and test holes ......................................... 36

2. Streamflow and infiltration rates for the tributary-stream sites ..................................... 38 
Appendix 1.--Completion information for selected wells and test holes.

[Locations are shown in fig. 6. Dash indicates no data.]

\begin{tabular}{|c|c|c|c|c|c|c|c|c|}
\hline $\begin{array}{l}\text { Well or } \\
\text { test-hole } \\
\text { number }\end{array}$ & Owner & $\begin{array}{c}\text { Year } \\
\text { Completed }\end{array}$ & $\begin{array}{c}\text { Type of } \\
\text { completion }\end{array}$ & Use $^{3}$ & $\begin{array}{c}\text { Geologic } \\
\text { unit }^{4}\end{array}$ & $\begin{array}{l}\text { Depth of well } \\
\text { or hole, in feet } \\
\text { below land } \\
\text { surface }\end{array}$ & $\begin{array}{l}\text { Casing depth, } \\
\text { in feet below } \\
\text { land surface }\end{array}$ & $\begin{array}{l}\text { Casing } \\
\text { diameter, } \\
\text { in inches }\end{array}$ \\
\hline 221 & U.S. Fish \& Wildlife & 1973 & $\mathbf{S}$ & $\mathrm{T}$ & Qsd & 115 & 75 & 5 \\
\hline 222 & U.S. Fish \& Wildlife & 1973 & $\mathbf{S}$ & $\mathrm{T}$ & Qsd & 100 & 80 & 14 \\
\hline $\overrightarrow{223}$ & U.S. Fish \& Wildlife & 1973 & $\mathbf{S}$ & $\mathrm{T}$ & Qsd & 62 & 22 & 5 \\
\hline 224 & U.S. Geological Survey & 1984 & $\mathbf{S}$ & 0 & Qsd & 34 & 29 & 2 \\
\hline 225 & U.S. Geological Survey & 1984 & $\mathbf{S}$ & 0 & Qsd & 45 & 40 & 2 \\
\hline 264 & Marsh Creek Church & 1978 & 0 & $\mathrm{H}$ & Qsd & 36 & 36 & 6 \\
\hline 269 & U.S. Fish \& Wildlife & 1977 & $\mathbf{S}$ & NP & Qsd & 93 & 73 & 14 \\
\hline 270 & U.S. Fish \& Wildlife & 1977 & $\mathbf{S}$ & NH & Qsd & 96 & 77 & 14 \\
\hline 271 & U.S. Fish \& Wildlife & 1977 & $\mathbf{S}$ & NP & Qsd & 97 & 70 & 14 \\
\hline 272 & U.S. Fish \& Wildlife & 1977 & $\mathbf{S}$ & NP & Qsd & 88 & 68 & 14 \\
\hline 296 & U.S. Geological Survey & 1984 & $\mathbf{S}$ & 0 & Qsd & 23 & 18 & 2 \\
\hline $\mathbf{2 9 7}$ & U.S. Geological Survey & 1984 & $\mathbf{S}$ & $\mathrm{O}$ & Qaf & 20 & 15 & 2 \\
\hline 299 & U.S. Geological Survey & 1984 & $\mathbf{S}$ & 0 & Qsd & 48 & 43 & 2 \\
\hline 300 & U.S. Geological Survey & 1984 & $\mathbf{S}$ & 0 & Qaf & 20 & 15 & 2 \\
\hline 324 & U.S. Geological Survey & 1984 & $\mathbf{S}$ & 0 & Qaf & 15 & 10 & 2 \\
\hline 325 & U.S. Geological Survey & 1984 & $\mathbf{S}$ & 0 & Qsd & 53 & 43 & 2 \\
\hline 344 & U.S. Fish \& Wildlife & 1977 & $\mathrm{~S}$ & 0 & Qsd & 60 & 20 & 2 \\
\hline 345 & U.S. Fish \& Wildlife & 1977 & $\mathrm{~S}$ & 0 & Qsd & 60 & 20 & 2 \\
\hline 346 & U.S. Fish \& Wildlife & 1977 & $\mathbf{S}$ & 0 & Qsd & 60 & 20 & 2 \\
\hline 347 & U.S. Fish \& Wildlife & 1977 & $\mathbf{S}$ & 0 & Qsd & 60 & 20 & 2 \\
\hline 348 & U.S. Geological Survey & 1984 & $\mathbf{S}$ & $\mathrm{O}$ & Qsd & 16 & 11 & 2 \\
\hline 349 & U.S. Fish \& Wildlife & 1977 & $\mathbf{S}$ & 0 & Qsd & 60 & 20 & 2 \\
\hline 374 & U.S. Geological Survey & 1984 & $\mathbf{P}$ & 0 & Qaf & 15 & 10 & 2 \\
\hline 405 & Webster, W. & 1967 & 0 & $\mathrm{H}$ & Qsd & 36 & 36 & 6 \\
\hline 406 & Miller, $\mathbf{R}$. & 1979 & $\mathrm{O}$ & $\mathrm{H}$ & Qsd & 45 & 45 & 6 \\
\hline 464 & U.S. Fish \& Wildlife & 1973 & $\mathrm{~S}$ & $\mathrm{~T}$ & Qsd & 96 & 56 & 5 \\
\hline 465 & U.S. Fish \& Wildlife & 1973 & $\mathbf{S}$ & $\mathrm{T}$ & Qsd & 108 & 68 & 5 \\
\hline 466 & U.S. Fish \& Wildlife & 1973 & $\mathbf{S}$ & $\mathrm{T}$ & Qsd & 102 & 62 & 5 \\
\hline 467 & U.S. Fish \& Wildlife & 1973 & $\mathrm{~S}$ & $\mathrm{~T}$ & Qsd & 105 & 85 & 14 \\
\hline 468 & U.S. Fish \& Wildlife & 1973 & $\mathbf{N}$ & $\mathrm{T}$ & Dck & 61 & - & - \\
\hline 469 & U.S. Fish \& Wildlife & 1973 & $\mathbf{N}$ & $\mathrm{T}$ & Dck & 64 & - & - \\
\hline 470 & U.S. Fish \& Wildlife & 1984 & $\mathbf{P}$ & 0 & Qsd & 73 & 69 & 6 \\
\hline 471 & U.S. Fish \& Wildlife & 1984 & $\mathbf{P}$ & $\mathrm{O}$ & Qsd & 47 & 42 & 6 \\
\hline
\end{tabular}




\begin{tabular}{|c|c|c|c|c|c|c|c|c|}
\hline $\begin{array}{l}\text { Well or } \\
\text { test-hole } \\
\text { number }\end{array}$ & Owner & $\begin{array}{c}\text { Year } \\
\text { Completed }\end{array}$ & $\begin{array}{c}\text { Type of } \\
\text { completion }^{2}\end{array}$ & $\mathrm{Use}^{3}$ & $\begin{array}{c}\text { Geologic } \\
\text { unit }^{4}\end{array}$ & $\begin{array}{c}\text { Depth of well } \\
\text { or hole, in feet } \\
\text { below land } \\
\text { surface }\end{array}$ & $\begin{array}{l}\text { Casing depth, } \\
\text { in feet below } \\
\text { land surface }\end{array}$ & $\begin{array}{l}\text { Casing } \\
\text { diameter, } \\
\text { in inches }\end{array}$ \\
\hline 472 & Walker, S. & - & $\mathrm{O}$ & $\mathbf{H}$ & Qsd & 85 & 85 & 6 \\
\hline 473 & Cleveland, C. & - & $\mathrm{U}$ & $\mathrm{H}$ & - & - & - & 6 \\
\hline 474 & Bent Barrel Club & - & $\mathbf{U}$ & $\mathrm{H}$ & - & 90 & - & 6 \\
\hline 475 & Christie, $\mathbf{R}$. & - & $\mathrm{O}$ & $\mathrm{H}$ & Qsd & 27 & 27 & 6 \\
\hline 476 & U.S. Fish \& Wildlife & 1984 & $\mathbf{S}$ & 0 & Qsd & 30 & 20 & 2 \\
\hline 477 & Terrell, $\mathrm{T}$ & 1984 & 0 & $\mathrm{H}$ & Qsd & 38 & 38 & 6 \\
\hline 478 & Peterson, A. & 1980 & $\mathrm{O}$ & $\mathrm{H}$ & Qsd & - & - & 6 \\
\hline 479 & Ward, L. & 1966 & $\mathbf{U}$ & $\mathrm{H}$ & Dck & - & - & 6 \\
\hline 480 & Ruland, C. & - & $\mathbf{U}$ & $\mathrm{H}$ & - & - & - & 6 \\
\hline 482 & Cooper, D. & 1977 & $x$ & $\mathbf{H}$ & Dck & 118 & 77 & 6 \\
\hline 483 & Bowers, G. & - & $\mathrm{T}$ & $\mathbf{H}$ & Qaf & 9 & 7 & 1 \\
\hline 484 & Bowers, B. & - & $\mathrm{T}$ & I & Qaf & 17 & 15 & 1 \\
\hline 485 & Faiver, G. & - & $\mathbf{T}$ & $\mathbf{S}$ & Qaf & 17 & 15 & 1 \\
\hline 486 & Decker, E. & 1984 & $x$ & $\mathrm{H}$ & Dck & 124 & 122 & 6 \\
\hline 199 & Giddings, $R$. & 1985 & $\mathbf{S}$ & $\mathrm{H}$ & Qsd & 81 & 77 & 6 \\
\hline 500 & Butler, M. & 1985 & $\mathbf{S}$ & $\mathrm{H}$ & Qsd & 86 & 82 & 6 \\
\hline 501 & Faiver, C. & 1985 & $\mathbf{S}$ & $\mathrm{H}$ & Qsd & 86 & 81 & 6 \\
\hline 502 & Bowers, G. & 1985 & $\mathbf{S}$ & $\mathrm{H}$ & Qsd & 90 & 85 & 6 \\
\hline 503 & Bowers, G. & 1985 & $\mathbf{S}$ & $\mathbf{H}$ & Qsd & 77 & 72 & 6 \\
\hline 504 & Butler, A. & 1985 & $\mathbf{S}$ & $\mathbf{H}$ & Qsd & 94 & 89 & 6 \\
\hline 505 & Faiver, G. & 1985 & $\mathbf{S}$ & $\mathrm{H}$ & Qsd & 78 & 73 & 6 \\
\hline 506 & Faiver, A. & 1985 & $\mathbf{S}$ & $\mathrm{H}$ & Qsd & 77 & 72 & 6 \\
\hline 507 & Medvid & 1985 & $\mathbf{S}$ & $\mathbf{H}$ & Qsd & 81 & 77 & 6 \\
\hline 508 & Faiver, G. & 1985 & $\mathbf{S}$ & $\mathbf{H}$ & Qsd & 75 & 71 & 6 \\
\hline 509 & Peterson, M. & 1985 & 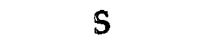 & $\mathrm{H}$ & Qsd & 81 & 77 & 6 \\
\hline 510 & Faiver, G. & 1960 & $\mathrm{~T}$ & $\mathrm{H}$ & Qaf & 15 & 13 & 1 \\
\hline 536 & Tighe & 1985 & $\mathrm{X}$ & $\mathbf{H}$ & Dck & 114 & 35 & 6 \\
\hline 541 & U.S. Fish \& Wildlife & 1975 & $\mathbf{N}$ & $\mathrm{T}$ & Qaf & 21 & - & - \\
\hline 542 & U.S. Fish \& Wildlife & 1975 & $\mathbf{N}$ & $\mathrm{T}$ & Qsa & 22 & - & - \\
\hline 543 & U.S. Fish \& Wildlife & 1975 & $\mathbf{N}$ & $\mathbf{T}$ & Qsa & 22 & - & - \\
\hline
\end{tabular}

${ }^{1}$ Sequential county number, which follows the two-letter Ti for Tioga County, assigned by the U.S. Geological Survey, Harrisburg, Pa.

${ }^{2} \mathrm{O}$, open end; $X$, open hole; $T$, wellpoint; $P$, slotted; $S$, screened; $N$, not completed; $U$, unknown.

${ }^{3} \mathrm{H}$, domestic; O, observation; T, test; S, stock; I, irrigation; NH, National Fisheries Research and Development Laboratory domestic; NP, National Fisheries Research and Development Laboratory production.

${ }^{4}$ Qsa, alluvium and swamp deposits; Qaf, alluvial-fan deposits; Qsd, stratified drift; Dck, Catskill Formation. 
Appendix 2.--Streamflow and infiltration rates for the tributary-stream sites.

[Flow and infiltration rates are in cubic feet per second. Positive infiltration rate indicates loss, negative rate indicates gain. Underscored numbers are distance along channel from farthest downstream bedrock outcrop to stream measurement site, in feet. Point of dryness is distance along channel from farthest downstream bedrock outcrop to point of stream dryness, in feet. $\mathbf{N}$ indicates no point of dryness; stream flows to Marsh Creek. Dash indicates no data. Locations shown in fig. 6.]

\begin{tabular}{|c|c|c|c|c|c|c|c|c|c|c|c|}
\hline \multirow[b]{2}{*}{$\begin{array}{c}\text { Stream } \\
\text { and date }\end{array}$} & \multirow{2}{*}{$\begin{array}{l}\text { Site } 1 \\
\text { Flow }\end{array}$} & \multicolumn{2}{|c|}{ Site 2} & \multicolumn{2}{|c|}{ Site 3} & \multicolumn{2}{|c|}{ Site 4} & \multicolumn{2}{|c|}{ Site 5} & \multirow[b]{2}{*}{$\begin{array}{l}\text { Point of } \\
\text { dryness }\end{array}$} & \multirow[b]{2}{*}{$\begin{array}{c}\text { Total } \\
\text { infiltration }\end{array}$} \\
\hline & & Flow & $\begin{array}{l}\text { Infil- } \\
\text { tration }\end{array}$ & Flow & $\begin{array}{l}\text { Infil- } \\
\text { tration }\end{array}$ & Flow & $\begin{array}{l}\text { Infil- } \\
\text { tration }\end{array}$ & Flow & $\begin{array}{l}\text { Infil- } \\
\text { tration }\end{array}$ & & \\
\hline $\begin{array}{l}\text { Asaph } \\
\text { Run }\end{array}$ & 1,050 & \multicolumn{2}{|c|}{1,650} & \multicolumn{2}{|c|}{2,540} & \multicolumn{2}{|c|}{3,640} & \multicolumn{2}{|c|}{ - } & & \\
\hline $07-20-83$ & 3.53 & - & - & - & - & - & - & - & - & 3,250 & 3.5 \\
\hline $06-28-84$ & 28.3 & 27.7 & .6 & 25.3 & 24 & 23.9 & 1.4 & - & - & $\mathbf{N}$ & 4.4 \\
\hline $10-05-84$ & 2.51 & 1.66 & .85 & .44 & 1.2 & - & - & - & - & 3,300 & 2.5 \\
\hline $12-18-84$ & 39.7 & 43.6 & -3.9 & 38.6 & 5.0 & 38.0 & .6 & - & - & $\mathbf{N}$ & 1.7 \\
\hline $02-27-85$ & 73.8 & 79.2 & -5.4 & 74.7 & 4.5 & 67.5 & 7.2 & - & - & $\mathbf{N}$ & 6.3 \\
\hline $03-27-85$ & 41.3 & 41.9 & -.6 & 35.9 & 6.0 & 36.6 & 7 & - & - & $\mathbf{N}$ & 4.7 \\
\hline $04-24-85$ & 13.4 & 10.8 & 2.6 & 9.38 & 1.4 & 8.67 & .71 & - & - & $\mathbf{N}$ & 4.7 \\
\hline $05-30-85$ & 6.90 & 4.63 & 2.3 & 4.21 & .42 & 211 & 2.1 & - & - & $\mathbf{N}$ & 4.8 \\
\hline $07-23-85$ & 2.21 & 1.52 & .69 & .57 & 95 & - & - & - & - & 3,240 & 2.2 \\
\hline 08-19-85 & 1.37 & - & - & - & - & - & - & - & - & 2,515 & 1.4 \\
\hline 09-05-85 & 2.32 & 1.97 & .35 & .73 & 1.2 & - & - & - & - & 3,200 & 2.3 \\
\hline $09-11-85$ & 5.70 & 5.28 & .42 & 4.00 & 1.3 & 1.81 & 2.19 & - & - & $\mathbf{N}$ & 3.8 \\
\hline $09-12-85$ & 4.19 & 3.15 & 1.0 & 1.89 & 1.3 & .59 & 1.30 & - & - & $\mathbf{N}$ & 3.6 \\
\hline $10-23-85$ & 2.04 & 1.18 & .86 & .26 & 92 & - & - & - & - & 2,685 & 2.0 \\
\hline \multicolumn{4}{|l|}{ Straight } & \multicolumn{2}{|c|}{1,775} & \multicolumn{2}{|c|}{2,570} & \multicolumn{2}{|c|}{ 3,705 } & & \\
\hline $07-19-83$ & 1.64 & - & - & - & - & - & - & - & - & 2,500 & 1.6 \\
\hline $06-28-84$ & 13.3 & - & - & 122 & 1.1 & - & - & 8.59 & 3.6 & $\mathbf{N}$ & 4.7 \\
\hline $10-05-84$ & .89 & 1.08 & -.19 & .52 & .56 & - & - & - & - & 2,355 & .89 \\
\hline $12-18-84$ & 224 & 226 & -2 & 20.9 & 1.7 & 18.5 & 24 & 16.2 & 24 & $\mathbf{N}$ & 6.2 \\
\hline $02-27-85$ & 328 & 31.9 & 9 & 34.4 & -2.5 & 31.3 & 3.1 & 24.8 & 6.5 & $\mathbf{N}$ & 8.0 \\
\hline $03-27-85$ & 19.8 & - & - & 18.4 & 1.4 & 15.0 & 3.4 & 13.0 & 2.0 & $\mathbf{N}$ & 6.8 \\
\hline $04-24-85$ & 5.26 & 5.02 & .24 & 4.65 & 37 & 3.29 & 1.4 & 1.05 & 2.2 & $\mathbf{N}$ & 4.2 \\
\hline 05-30-85 & 3.07 & - & - & - & - & .04 & 3.0 & - & - & 3,040 & 3.1 \\
\hline $07-23-85$ & 1.11 & 1.21 & -.10 & .79 & .42 & - & - & - & - & 2,355 & 1.1 \\
\hline 08-19-85 & .81 & - & -- & - & - & - & - & - & - & 2,330 & .81 \\
\hline $09-04-85$ & 1.08 & 1.20 & -.12 & .76 & .44 & - & - & - & - & 2,340 & 1.1 \\
\hline $10-23-85$ & .74 & .70 & .04 & .37 & 33 & - & - & - & - & 2,180 & .74 \\
\hline
\end{tabular}


Appendix 2.--Streamflow and infiltration rates for the tributary-stream sites (continued).

\begin{tabular}{|c|c|c|c|c|c|c|c|c|c|c|c|}
\hline \multirow[b]{2}{*}{$\begin{array}{c}\text { Stream } \\
\text { and date }\end{array}$} & \multirow{2}{*}{$\begin{array}{l}\text { Site } 1 \\
\text { Flow }\end{array}$} & \multicolumn{2}{|c|}{ Site 2} & \multicolumn{2}{|c|}{ Site 3} & \multicolumn{2}{|c|}{ Site 4} & \multicolumn{2}{|c|}{ Site 5} & \multirow[b]{2}{*}{$\begin{array}{l}\text { Point of } \\
\text { dryness }\end{array}$} & \multirow[b]{2}{*}{$\begin{array}{c}\text { Total } \\
\text { Infiltration }\end{array}$} \\
\hline & & Flow & $\begin{array}{c}\text { Infil- } \\
\text { tration }\end{array}$ & Flow & $\begin{array}{l}\text { Infil- } \\
\text { tration }\end{array}$ & Flow & $\begin{array}{c}\text { Infil- } \\
\text { tration }\end{array}$ & Flow & $\begin{array}{c}\text { Infil- } \\
\text { tration }\end{array}$ & & \\
\hline $\begin{array}{l}\text { Dantz } \\
\text { Run }\end{array}$ & 0 & \multicolumn{2}{|c|}{350} & \multicolumn{2}{|c|}{725} & \multicolumn{2}{|c|}{ - } & \multicolumn{2}{|c|}{ - } & & \\
\hline 07-19-83 & .71 & - & - & - & - & $\infty$ & - & - & - & 780 & .71 \\
\hline $05-17-84$ & 5.78 & - & - & 5.26 & .52 & - & - & - & - & $\mathbf{N}$ & - \\
\hline $06-20-84$ & 3.40 & $\infty$ & - & 2.27 & 1.13 & - & - & - & - & - & - \\
\hline $07-18-84$ & 1.44 & 1.35 & .09 & .46 & .89 & - & - & - & - & 1,145 & 1.4 \\
\hline $07-26-85$ & .74 & - & - & - & - & - & - & - & - & 735 & .74 \\
\hline $\begin{array}{l}\text { Canada } \\
\text { Run }\end{array}$ & 0 & \multicolumn{2}{|c|}{1,050} & \multicolumn{2}{|c|}{1,495} & \multicolumn{2}{|c|}{-} & \multicolumn{2}{|c|}{$\infty$} & & \\
\hline $07-12-84$ & 7.38 & 5.93 & 1.5 & - & - & - & - & - & - & $\mathbf{N}$ & - \\
\hline $07-17-84$ & 2.87 & 1.42 & 1.5 & .16 & 1.26 & - & - & - & - & 1,645 & 2.9 \\
\hline $07-24-84$ & 1.28 & .17 & 1.1 & - & - & - & - & - & - & 1,200 & 1.3 \\
\hline $07-26-84$ & .91 & - & - & - & - & - & - & - & - & 900 & .91 \\
\hline $\begin{array}{l}\text { Heise } \\
\text { Run }\end{array}$ & 0 & 66 & & 1,8 & & & & & & & \\
\hline $07-18-83$ & - & .25 & - & .22 & .03 & - & - & - & - & $\mathbf{N}$ & - \\
\hline $05-17-84$ & - & 256 & - & 3.09 & -.53 & - & - & - & $\infty$ & $\mathbf{N}$ & - \\
\hline $06-20-84$ & - & .73 & - & .65 & .08 & - & - & - & $\infty$ & $\mathbf{N}$ & - \\
\hline 07-19-84 & - & .28 & - & .33 & -.05 & - & - & - & - & $\mathbf{N}$ & - \\
\hline $11-05-84$ & 1.66 & 1.81 & -.15 & 1.94 & -.13 & - & - & - & - & $\mathbf{N}$ & -.28 \\
\hline 07-26-85 & 29 & .15 & .14 & .25 & -.10 & - & - & - & - & $\mathbf{N}$ & .04 \\
\hline
\end{tabular}






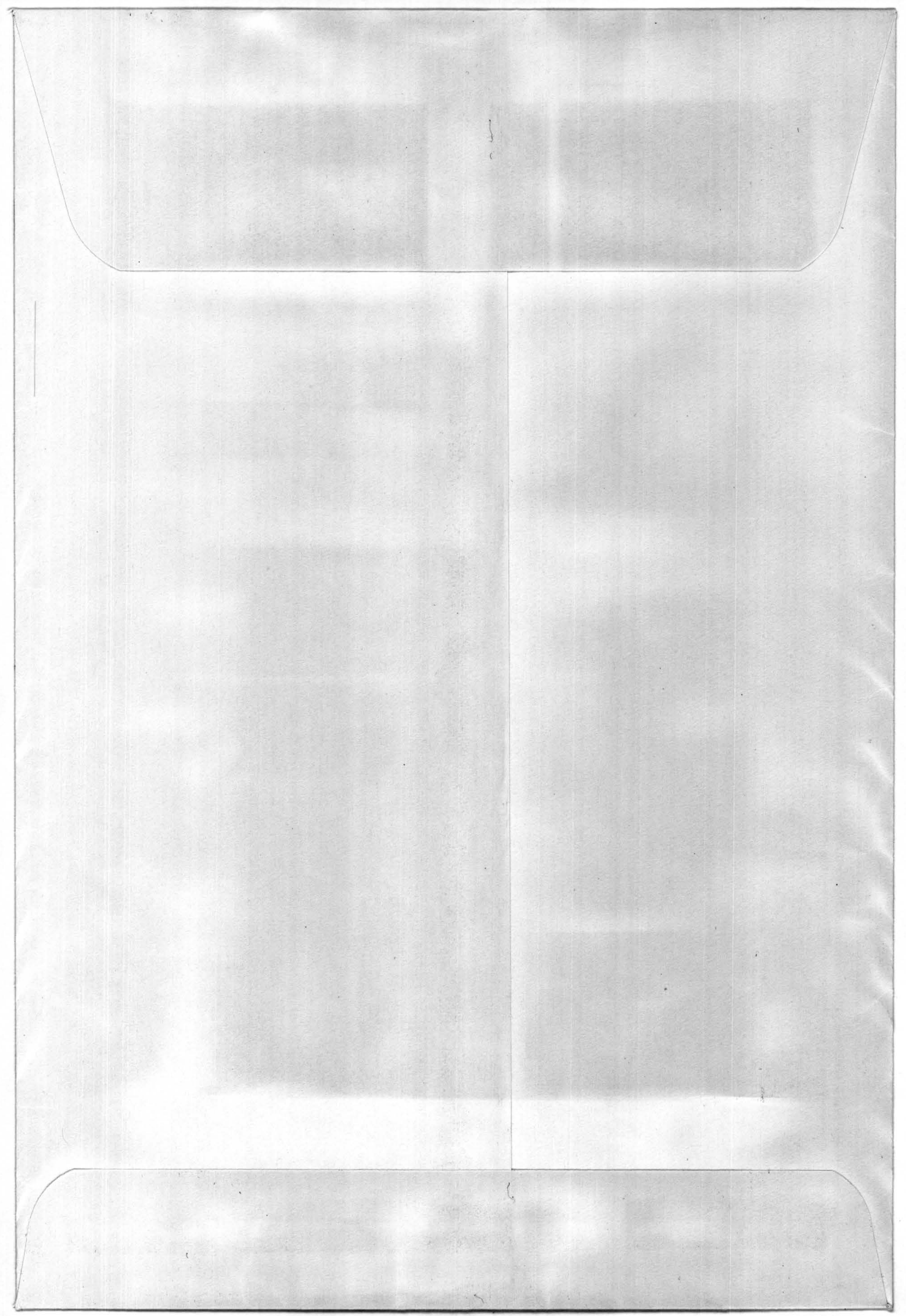


:

5

总

0

蛋

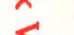

产

$z$

马

8

ํㅗㄹ

7

氙

这.

鹿

츔

点?

角 